\title{
Raudondvaris prie Raudonojo Dvaro ežero: 400 metų istorinès raidos atspindžiai
}

Indrè Kačinskaitè

Kultūros paveldo centras

Ašmenos g. 10, LT-01135 Vilnius

indre.kacinskaite@kpc.lt

— Šio straipsnio tikslas - pateikti turimas žinias apie šiandien dar egzistuojantị Gulbinų Raudondvario dvaro sodybos ansambli, kuriame dominuoja medinis užstatymas, ịvertinti šio objekto svarbą Lietuvos dvarų paveldui. Medinis dvarų paveldas - bene labiausiai šiandien nykstanti, besikeičianti paveldo dalis, dẻl savo apgailètinos būklès dažnai estetiškai nebepatraukli, vartotojiškos visuomenės vertinama kaip jau prarasta - ,argi čia dvaras, rūmai?“, todèl verta kur kas išsamesnès analizès.

Straipsnyje, remiantis istoriniais, kartografiniais šaltiniais, architektūriniais tyrimais, atskleidžiama vienos seniausių išlikusių medinių dvarų sodybų Lietuvoje - Raudondvario sodybos Riešės seniūnijoje, Vilniaus rajone, istorinio vaizdo kaita, pastatų architektūra, atspindinti 400 metu trukusios raidos bruožus.

Reikšminiai žodžiai: Raudondvaris (Vilniaus r.), dvaro sodyba, istorija, kompozicija, architektūra, piešinys, XVII a. 
Vilniaus rajono Riešès seniūnijoje esanti Raudondvario dvaro sodyba iš kitų Lietuvos Raudondvarių skiriasi tuo, kad joje raudono rūmo nèra, tačiau kaip pasakoja vietiniai žmonès, buvo aptverta aukšta raudona (plytų mūro ?) tvora, todèl ir igavo toki pavadinimą. Sovietmečiu sodyba nebuvo „reprezentaciniame“, ideologizuotame Kultūros paminklų sąraše, nesaugota kaip Lietuvos dvarų paveldo sudėtinė dalis. Iš kompleksiškai išlikusios Raudondvario dvaro sodybos tik vienas statinys - medinis lobynas, kurio dinamiškas siluetas dominavo dvaro sodybos aplinkoje ir savo architektūrinėmis formomis išsiskyrè tradiciniame kraštovaizdyje, buvo ịrašytas ì Lietuvos TSR kultūros paminklų Vietinès reikšmès architektūros paminklų sąrašą ${ }^{1}$. Raudondvario dvaro parkas dar 1957 m. paskelbtas valstybès saugomu, $1986 \mathrm{~m}$. priskirtas prie vietinès reikšmės gamtos paminklų ${ }^{2}$. Atkūrus nepriklausomybę, $1991 \mathrm{~m}$. dvaro sodyba kartu su kitomis 789 dvaru sodybomis buvo įtraukta ị Naujai išaiškinamų istorijos ir kultūros paminklų sąrašą, o 2019 m. jai nustatytos vertingosios savybės ${ }^{3}$.

Sovietmečiu didžiausio tyrèjų dėmesio yra sulaukęs Raudondvario dvaro sodybos išskirtinis statinys - lobynas. Šio architektūros paminklo istorinius tyrimus atliko istorikai V. Gromulas (1968), Romanas Firkovičius $(1981)^{4}$. Apie Raudondvario dvaro sodybą, joje stovėjusius statinius $1957 \mathrm{~m}$. išsamius duomenis „Raudonojo dvaro Vilniaus rajone aprašyme“ pateikè architektas Stasys Abramauskas ${ }^{5}$. Atkūrus nepriklausomybę medinės dvarų sodybos tirtos menotyrininkès Dalès Puodžiukienès ${ }^{6}$. Barokinių dvarų

1 Lietuvos TSR kultūros paminklų sarašas, Vilnius: Pergalè, 1973, p. 435.

2 Antanas Tauras, Mūsu parkai, Vilnius: Mokslas, 1989, p. 3; Gediminas Isokas, Lietuvos gamtos paminklai, Vilnius: Mintis, 1995, p. 384.

3 Raudondvario dvaro sodyba, vad. Riešès Raudondvario (917). Vilniaus rajono sav., Riešès sen., Raudondvario k., Kultūros vertybių registras, [interaktyvus], 2019, [žiūrèta 2019-10-01], https:// kvr.kpd.lt/\#/static-heritage-search.

4 V. Gromulas, Riešès Raudondvario architektūrinio ansamblio trumpos istorinès žinios, LTSR kultūros ministerija. Spec. mokslinė restauracinė gamybinė dirbtuvė, Vilnius, 1968, in: Vilniaus regioninis valstybės archyvas (toliau - VRVA), f. 1019, ap. 11, b. 90; Romanas Firkovičius, Raudondvario dvaro lobynas, Vilniaus r. Atv 801, Lietuvos TSR architektūros paminklai. Istoriniai tyrimai, 1981, in: VRVA, f. 1019, ap. 11, b. 236, 1. 63-65.

5 Stasys Abramauskas, Raudonojo Dvaro buv. dvaro Vilniaus rajone aprašymas, Dokumentų byla apie Vilniaus rajono Raudondvario dvarą ir parką, 1975, in: Kultūros paveldo centro paveldosaugos biblioteka (toliau - KPCPB), f. 3, ap. 1, s. v. 231.

6 Dalè Puodžiukienè, Medinès ponu namu archtektūros raida Lietuvoje XVI a. vid. XIX a. vid.: Daktaro diseracija, Humanitariniai mokslai, menotyra (03H), Vytauto Didžiojo universitetas, Kaunas, 2011; Eadem, „Dvarų sodybų architektūra“, in: Lietuvos architektūros istorija. Lietuvos etniné architektūra nuo seniausiu laiku iki 1918 m., t. IV, Vilnius: Savastis, 2014, p. 354-482; Eadem, „Dvaro sodybos pastatas povalušas: funkcija, forma ir tradicija“, in: Acta Academiae Artium Vilnensis, Vilnius, 2017, t. 86-87: (Ǐ̌)koduota istorija architektūroje, sud. Rasa Butvilaitè, Edita Povilaitytè-Leliugienè, p. 149-165. 
sodybų, taip pat ir Raudondvario sąranga vertinta ir šio straipsnio autorès tekste, skirtame Lietuvos Didžiosios Kunigaikštystès barokinei dvaro sodybai ${ }^{7} .2002$ m. Raudondvario dvaro sodybos dviejų pastatų žvalgybinius mūro tyrimus, svarbius dvaro sodybos pradiniam laikotarpiui nustatyti, atliko architektè Birutè Gudynaitè ${ }^{8}$. Sodybos archeologiniai tyrimai, galėję svariai papildyti turimas žinias apie ši istorinį objektą, nebuvo atlikti. Esama sodybos būklè straipsnio autorès fiksuota 2018 metais $^{9}$. Svarbiausiais istoriniais šaltiniais, rašant straipsnị, išliko $1764 \mathrm{~m}$. Raudondvario dvaro inventorius bei XIX a. ir XX a. pradžios dvaro sodybos ikonografinè, kartografinè medžiaga, sudarę galimybę nuosekliai pažvelgti ị šimtmečiais trukusią dvaro sodybos raidą, jos vaizdo kaitą ${ }^{10}$.

\section{SODYBA: istorija, sudètis, kompozicija}

Raudondvario dvaro savininkų indèlis, kuriant šią sodybą, nėra plačiau tyrinètas. 1690 m. dūmų tarifuose minima Gulbinų Riešè su karčema ir malūnu priklausè p. Goliušui (Goliusz) ${ }^{11}$. Iš 1864 m. inventoriaus sužinome, kad XVIII a. viduryje dvaras buvo Mstislavlio teisinio seniūno Mikalojaus ir Barboros iš Kapčių Lopacinskių bei Puzinų nuosavybè ${ }^{12}$. Iš jų 1764 m. dvarą įsigijo Jonas Augustas ir Konstancija iš Pliaterių Hilzenai (Hylzeny), pastarujų turto paveldètojais buvo Idzis (Idzy) ir Marija iš Bžostovskių Hilzenai. Su vèlesnių savininkų - generolo leitenanto Kazimiero ir Jadvygos iš Pliaterių Ziberkų ${ }^{13}$, dvarą valdžiusių nuo 1798 m., pavardèmis siejama klasicistinė sodybos rekonstrukcija. Žinoma, kad 1841 m. Kazimieras Pliateris Raudondvarị pardavė dvarininkui Stanislovui Jasinskiui ${ }^{14}$. Tarpukaryje dvaras priklausė buvusiam Vilniaus apskrities vyr. agronomui,

7 Indrè Kačinskaitè, „Barokinė dvaro sodyba: istorinio vaizdo retrospekcija“, in: Kultūros paminklai, Nr. 19, Vilnius: Savastis, 2015, p. 35-56.

8 Birutė Gudynaitè, Bijutiškio dvaro sodybos IP 437/At ir Raudondvario dvaro sodybos IP 910/At dviejų pastatų fiziniai tyrimai, Vilnius: Kultūros paveldo centras, 2002.

9 Raudondvario dvaro sodyba, vad. Riešès Raudondvario (917), [interaktyvus], [žiūrèta 2020-11-18], https://kvr.kpd.lt/\#/static-heritage-search.

10 Riešès arba Raudondvario dvaro inventorius (toliau - Invenntorius), 1764, in: LVIA, s. a. $4778,1.428-431$.

11 Metryka Litewska. Rejestry podymnego Wielkiego Księstwa Litewskiego Województwo wileńskie 1690 r., Optracowal Andrzej Rachuba, Warszawa: Państwowe wydawnictwo naukowe, 1989, 1. 100 .

12 Inventorius, 1.428.

13 Romanas Firkovičius, op. cit., l. 63.

14 Statistinis ir inventorinis Raudondvario dvaro aprašymas, 1847, in: LVIA, f. 394, ap. 1, b. $191,1.1$; b. 444, l. 88 . 

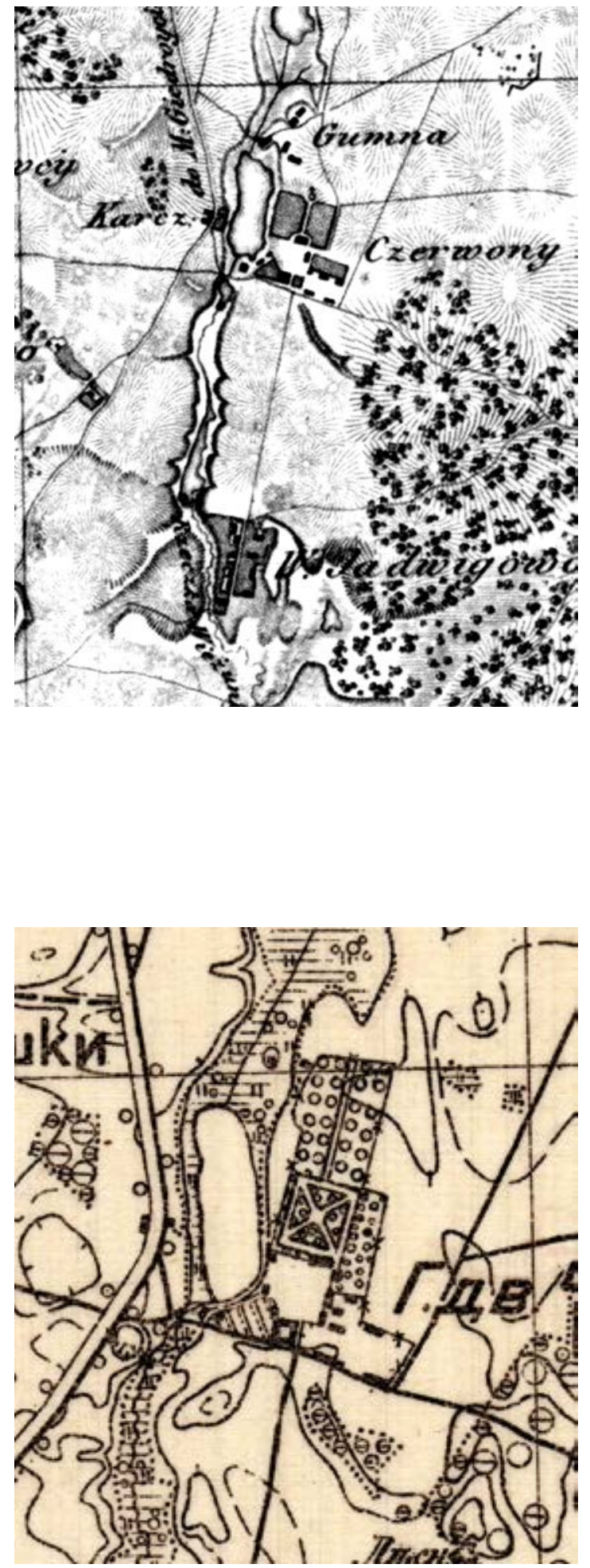

Raudondvario dvaras. Vilniaus apylinkiu XIX a. pradžios žemèlapis, in: Lietuvos XVII-XIX a. pradžios ikonografijos ir kartografijos šaltiniai Švedijoje, priedas Nr. XIX

Raudondvaris Manor. Map of the Vilnius environs of the early $19^{\text {th }}$ century
2

Raudondvario dvaro planas, [interaktyvus], 1891, [žiūrèta 2019-10-01], maps.mapywig. $\mathrm{org} / \mathrm{m} /$ Russian_and_Soviet_maps/series/025K Polsha_1939/XII-18-I_1939_LoC_G6520_s25_. R8.jpg?fbclid = IwAR0HtIZsXWNRsw5DNI Cr80aTQ DtI5PA7iz5C50GijVLBOjfONK9hH4̄U Plan of the Raudondvaris Manor, 1891 
dvarininkui Stanislovui Sinkevičiui (m. apie 1937), palaidotam Riešės kapinèse $^{15}$. Valdant Jasinskiams, vèliau Sinkevičiams vyko ryškiausi XIX a. antros pusės - XX a. pirmos pusès dvaro pertvarkymai.

Ankstyviausias žinomas dvaro sodybos vaizdas užfiksuotas 1764 m. dvaro inventoriuje (toliau - Inventorius) ${ }^{16}$. Jame nurodoma, kad tuo metu išsidèstę aplink centrinị kiemą stovèję: rūmai, oficina, trys rūsiai, lobynas, administracinis pastatas, arklidè, grūdų sandèlis, diendaržinis tvartas. Toliau, prie ežero: bravoras su jaučių tvartu šalia; skalbykla, sujungta su kalve; vandens ir vėjo malūnai; kluonienoje - dviejų tipų klojimai: vienas javams laikyti ir du javams apdoroti (tok), ir plytinè su mūrininko namu ${ }^{17}$. Tokią Raudondvario dvaro sodybos sąrangą galima apibūdinti kaip tradicinę, nuo XVII a. antros pusės plitusią Lietuvos Didžiojoje Kunigaikštystėje, sudarytą iš centrinio kiemo, apstatyto gyvenamaisiais ir ūkiniais pastatais, gamybinès dalies ežero pakrantèje ir kluonienos ${ }^{18}$. Žinoma, kad jau XVII a. viduryje visuotinai nusistovèjo ir tradicinè reprezentacinė dvaro centrinio kiemo sudètis, kurią kaip pavyzdinę XVII a. viduryje nurodè Jokūbas Kazimieras Hauras. Tokị dvaro kiemą sudarè dvarininko namas, lobynas, svirnas grūdams, tvartai žirgams ir pagalbiniai ūkiniai pastatai ${ }^{19}$. Sprendžiant iš Inventoriaus, Raudondvario dvaro sodybos centrinio kiemo vaizdas buvo artimas aprašytajam. Rūmai stovėjo kiemo centrinèje dalyje, kieme minimas šulinys su stogeliu, remiamu keturių stulpų bei rentiniu vandeniui sem$\mathrm{ti}^{20}$. Architektūros istorijos duomenys nurodo, kad didikų ir stambių bajoru sodybose jau nuo XVII a. pradžios centrinio kiemo erdvė imta organizuoti kryptingai - jai suteikiama reprezentacinė išraiška, o rūmai tapo kompoziciniu centru ${ }^{21}$. Ir šiandien, patekus ị Raudondvario dvaro sodybos centrinị kiemą, dèmesingesnis lankytojas pamatys, kad kiemo centrinę erdvę perimetru vis dar formuoja dvarininko namas (rūmai), lobynas, buvusi oficina (?), arklidè, du svirnai bei ūkinis pastatas. Raudondvario dvaro sodybos didelis centrinis kiemas - „dwor“, nors ir pakitęs, vis dar yra išskirtinis šios

\footnotetext{
15 Romanas Firkovičius, op. cit., 1. 63.

16 Inventorius, 1. 428-433.

17 Ibid.

18 Indrè Kačinskaitè, op. cit., p. 40.

19 Dalè Puodžiukienè, Lietuvos architektūros istorija IV: Lietuvos etninè architektūra nuo

20 Inventorius, 1. 430 (atvartas).

21 Dalė Puodžiukienė, „Dvarų sodybų architektūra“, in: Lietuvos architektūros istorija, t. IV: Lietuvos etninè architektūra nuo seniausiu laiku iki 1918 m., p. 362.
} seniausių laiku iki 1918 m., p. 362. 


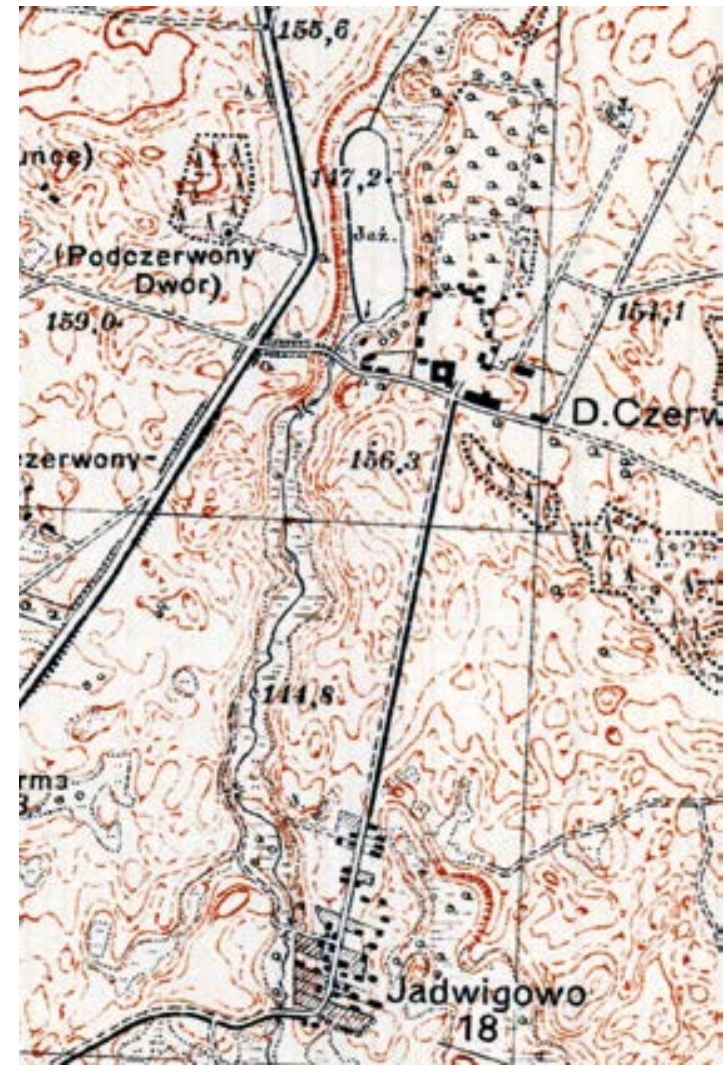

3.

Raudondvario dvaro planas, [interaktyvus], 1933, [žiūrèta 2019-10-01], maps.mapywig.org/m/ WIG_maps/series/025K/P29-S40-I RZESZA_1933_300dpi.jpg

Plan of the Raudondvaris Manor, 1933

sodybos erdvès organizavimo bruožas. Tai, kad šio kiemo formavimosi pradžia siekia XVII a., nurodo ir dviejų išlikusių pagrindinių sodybos pastatų: dvarininko namo (rūmų) ir lobyno mūro architektūriniai tyrimai ${ }^{22}$.

XIX a. pradžios plane užfiksuotas dvaro sodybos vaizdas jau pakitęs: kelio iš Vilniaus ị Giedraičius rytinėje dalyje ežero pakrantėje dominuoja ištęsto stačiakampio formos pagrindinis kiemas su perimetru stovinčiais svarbiausiais pastatais, prie jo iš rytų šliejasi suformuotas ūkinis kiemas, vakarinëje dalyje ties ežeru telkiasi gamybiniai pastatai, o šiaurinëje - už dvarininko namo ir sodo nurodoma nutolusi kluoniena. Rytinëje ežero pusèje šalia minèto kelio į Giedraičius pažymèta dvaro karčema [1 il.]. Akivaizdu, kad kluoniena, buvusi šalia dvaro centrinio kiemo (inventoriuje nurodoma, kad į kluoną einama iš kiemo), iškelta ị nuošalesnę vietą, už dvaro sodybos 
sodo. Rašytiniai šaltiniai taip pat paliudija, kad $1804 \mathrm{~m}$. dvaras buvęs medinis, vieno aukšto, prie jo plytėjo reguliaraus suplanavimo vaismedžių sodas, buvo plytinè, degtinès varykla, malūnas ${ }^{23}$.

XIX a. anroje pusėje - XX a. pradžioje sodyba plètėsi. Išlikusiuose 1891 m., 1933 m. planuose atsispindi esminiai Raudondvario dvaro sodybos pokyčiai: šiaurinėje dalyje nebeliko kluonienos, o jos vietą užėmė už dvarininko namo parko tęsinyje ịveistas naujas sodas [2, 3 il.]. Padaugejjo ir pastatų, pastatytų pagrindinio kiemo perimetru ir ūkinèje bei gamybinèje dalyse. Susiformavusi dvaro sodybos planinė erdvinė struktūra ankstyvu sovietmečiu dar buvo gerai išlikusi, tik parko teritorijoje atsirado keletas naujų pastatu [4 il.]. Nubrèžti sąsajas su XVIII a. - XIX a. pirmos pusės sodybos vaizdu ir „perskaityti“ šiandien išlikusią sodybos sąrangą padeda architekto Stasio Abramausko $1975 \mathrm{~m}$. dvaro sodybos aprašymas, kuriame akcentuota dvaro sodybos pagrindinè kompozicinė priemonė - ašis: „visa dvaro sodyba su ūkiniu kiemu, pagrindiniu gyvenamuoju pastatu bei parku yra parkinèje dalyje ašinès kompozicijos“. „Ant ašies buvęs taipogi pagrindinis ịvažiavimas dvaro sodybon iš pietinès jos pusès. I sodybą vedė tankiai kaštonų medžiais apsodinta alèja, kurios medžiai 1940 metų žiemą didele dalimi iššalo, po ko buvo iškirsti. ${ }^{24}$ XIX a. pirmos pusès klasicizmo planavimui būdinga išryškinta kompozicinè ašis tuo metu jungè ịvažiavimo alèją, kiemą su dvarininko namu centre ir parką [žr. 1-3 il.]. Ši ašinio planavimo schema priskirtina itin paplitusiam Lietuvos ir Lenkijos valstybėje ašinės kompozicijos dvarų sodybų tipui. Akivaizdūs bandymai bajorų sodybose sujungti kiemą priešais rūmus, pačius rūmus su už jų esančiu sodu ị vientisą kompozicinę sistemą pastebimi jau XVII a. antroje puseje ${ }^{25}$. Raudondvario dvaro sodybos suplanavimas atitiko šią schemą ir XIX a. pirmoje pusėje pasižymëjo išvystyta kompozicijos ašimi, jungusia ne tik pagrindinius šios dvaro sodybos struktūrinius elementus, bet ir jos tęsinyje įkurtą, dvarui priklausiusi gatvinị Jadvygiškių kaimą. Tačiau šios sodybos centrinès dalies kompozicijai nebuvo būdinga klasikinè ašinė simetrija, dominavusi barokinio ir klasicistinio laikotarpio ansambliuose, kai abipus rūmų statytos dažnai identiškos arklidès, oficinos (Liubavas, Biržuvènai, Mitèniškès, Paliesė). Raudondvario stambus, ištęsto stačiakampio formos centrinis kiemas, nors ir esantis ašinėje kompozicijoje, liko artimas XVII a.

23 Vilniaus gubernijos matininko statistinès žinios, 1804, in: LVIA, f. 526, ap. 1, b. 4, l. 6.

24 Stasys Abramauskas, op. cit., 1. 1.

25 Indrè Kačinskaitè, op. cit., p. 51. 


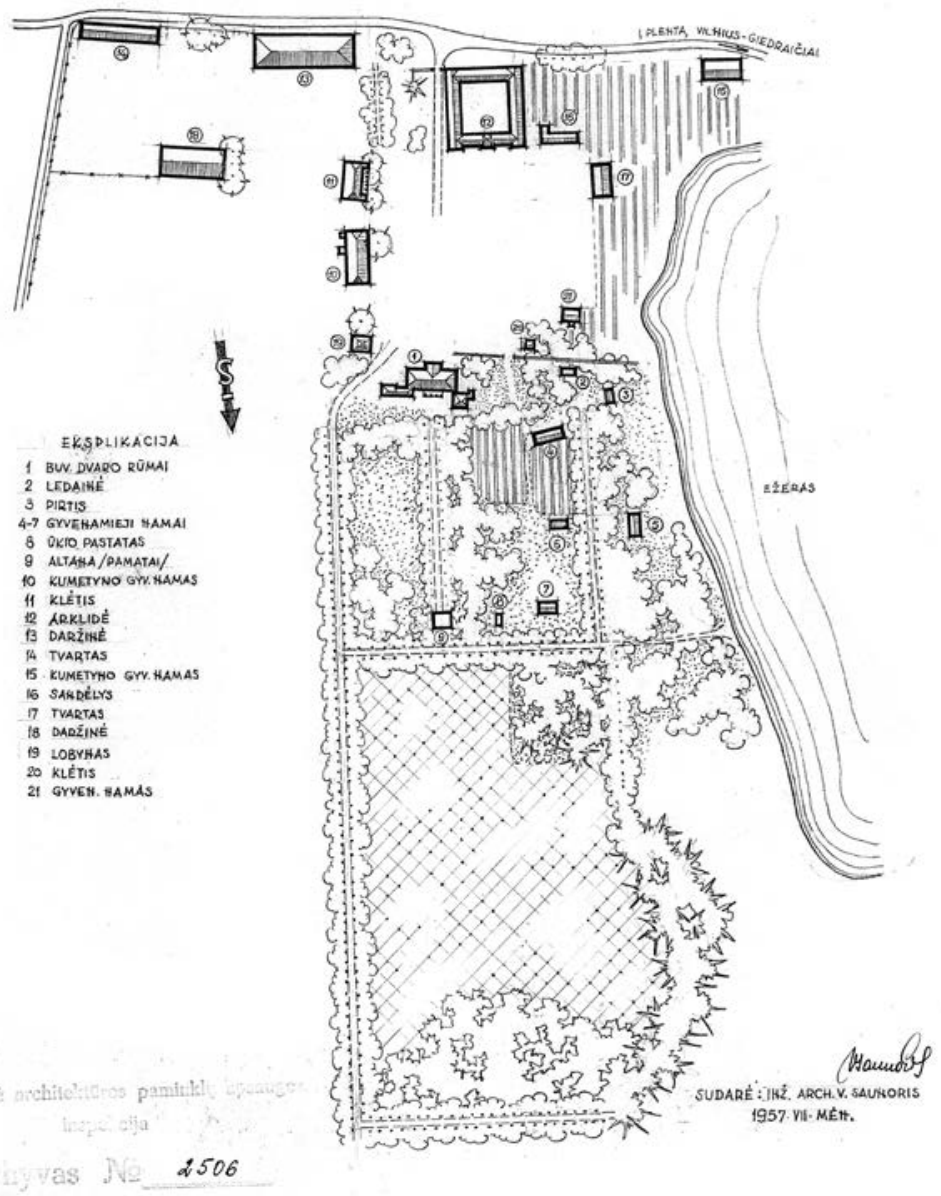

4.

Raudondvario dvaro sodybos situacijos planas, sud.

Situation plan of the Raudondvaris Manor, 1957

V. Saunoris, 1957, KPCPB, brèžinys Nr. 2506 


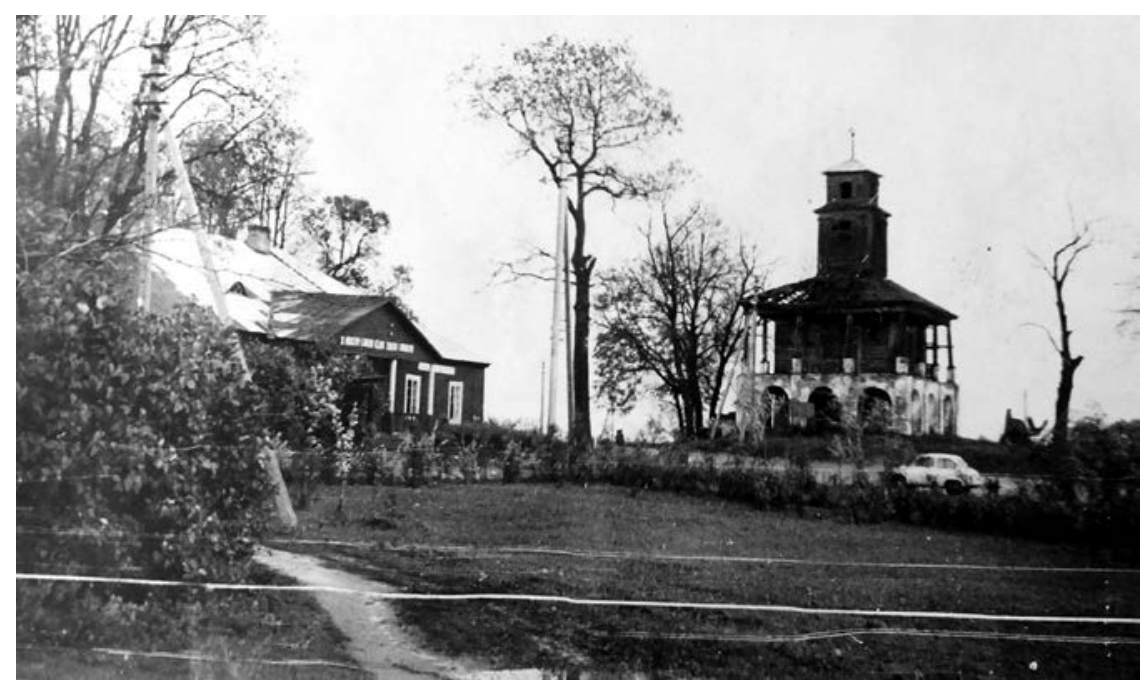

5.

Raudondvario dvaro sodyba, Alfonso Lagunavičiaus nuotrauka, 1968, KPCPB, f. 5, ap. 1, s. v. 118, 1. 6

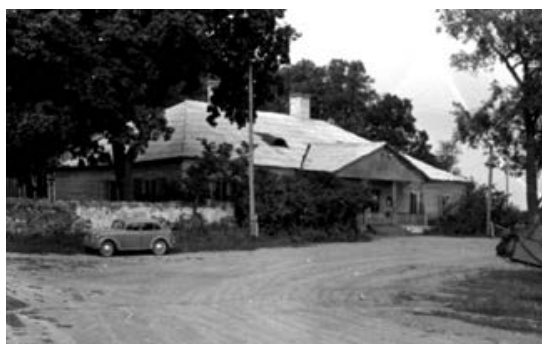

6.

Raudondvario dvaro sodybos dvarininko namo vakarų ir pietų fasadai, V. Miliūkščio nuotrauka, 1957, KPCPB, f. 41, architektūra 2756

West and south façades of the landowner's house of the Raudondvaris Manor, 1957

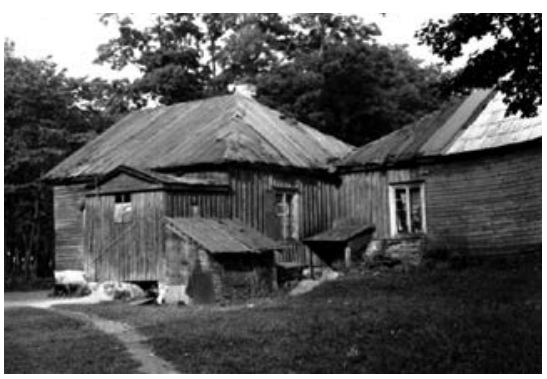

Raudondvaris Manor, 1968

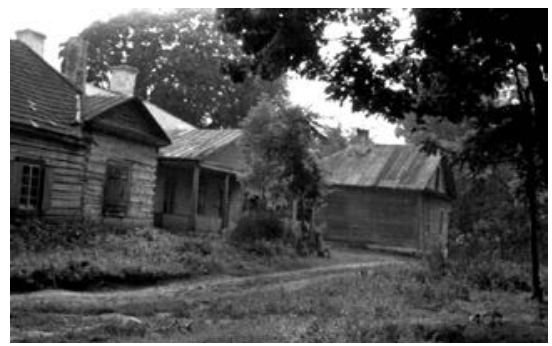

7.

Raudondvario dvaro sodybos dvarininko namo šiaurès fasadas, vakarų priestatas, V. Miliūkščio nuotrauka, 1957, KPCPB, f. 41, architektūra 2756

North façade and the west wing of the landowner's house of the Raudondvaris Manor, 1957

8.

Raudondvario dvaro sodybos dvarininko namo rytų fasadas, rytų priestatas, V. Miliūkščio nuotrauka, 1957, KPCPB, f. 41, architektūra 2756

East façade and the east wing of the landowner's house of the Raudondvaris Manor, 1957 
paplitusiai uždarų, perimetru pastatais apstatytų, su dvarininko namu centre kiemų struktūrai (Pavilkijys, Aštrioji Kirsna, Maišiagala) ${ }^{26}$.

\section{DVARININKO NAMAS IR LOBYNAS}

XXa. pabaigoje Raudondvario dvaro sodyboje dar buvo galima išvysti gerai išlikusią, tradiciniam mediniam dvarui būdingą statinių architektūrą, atspindinčią šimtmečiais besiformavusị Lietuvos Didžiojoje Kunigaikštystèje stambaus bajoro gyvenimo būdą ir skonį [5-8 il.]. Šiandien kuklių architektūrinių formų medinis vieno aukšto dvarininko namas sunkiai primena paveldo objektą - istorinės architektūrinès detalès menkai išlikusios, dominuoja utilitarios architektūrinės formos. Pasitelkę istorinius, architektūrinius tyrimus, sužinome kur kas sudètingesnę statinio istoriją. $2002 \mathrm{~m}$. priešais dvarininko namo pagrindinio fasado pietrytinị kampą po asfalto danga (galimą patekimo vietą nurodè vaikai) aptikti mūriniai skliautuoti rūsiai. Pagal mūrų charakteristikas jie formuoti XVII a. pradžioje vakarų ir rytų kryptimi. Dalis rūsių buvo išlikusi ir po mediniu pastatu, ị rūsius vedè mūriniai sraigtiniai laiptai ${ }^{27}$ [9 il.]. 1764 m. Raudondvario dvaro sodybos inventoriuje paminèti trys rūsiai. Vienas iš jų - prie dvarininkų namo išėjus „po dešine ranka“, kitas - po lobynu, o trečias - mažytis, $\underset{i}{i}$ kurị mūriniais laiptais patenkama iš stalų menès rūmuose $^{28}$. Šis trečiasis ir būtų „,naujai atrastas“ 2002 m. [10 il.].

Inventoriuje nurodoma, kad XVIII a. viduryje šio pastato būta puošnaus. Stogas dengtas čerpèmis, o jo forma, sprendžiant pagal 6 langų alave simetrinị išdèstymą, turèjusi būti mansardinè. Minimi pastogèje įrengti du ,altankomis“ pavadinti mezoninai. Jų centre - trys langeliai, suskaidyti ị 2 dalis, turèję vidines vienvèrias langines. Septintasis, didesnis langas buvęs virš prieangio. Virš stogo kilo keturi kaminai, o prieangio viršuje buvo įrengti du vandens nuleidimo vamzdžiai, užsibaigiantys gargolomis, inventoriuje pavadintomis „slibinais“. Dvivèrių langinių, taigi ir langų, nurodyta buvus dvidešimt ${ }^{29}$. Rūmų viduje pagrindinès patalpos koncentruotos pastato centre: pro pagrindines duris buvo patenkama ị priemenę, už kurios ịrengta salè, iš jos - tiesioginis išẻjimas i sodą. Dešinèje buvo durys ị stalų menę, už jos - „pono apartamentai“: pereinamasis kambarys,

27 Birutė Gudynaitè, op. cit., p. 11. Po vakarine pastato dalimi išlikęs vėlesnès statybos rūsys.

28 Inventorius, 1. 430 (atvartas). 

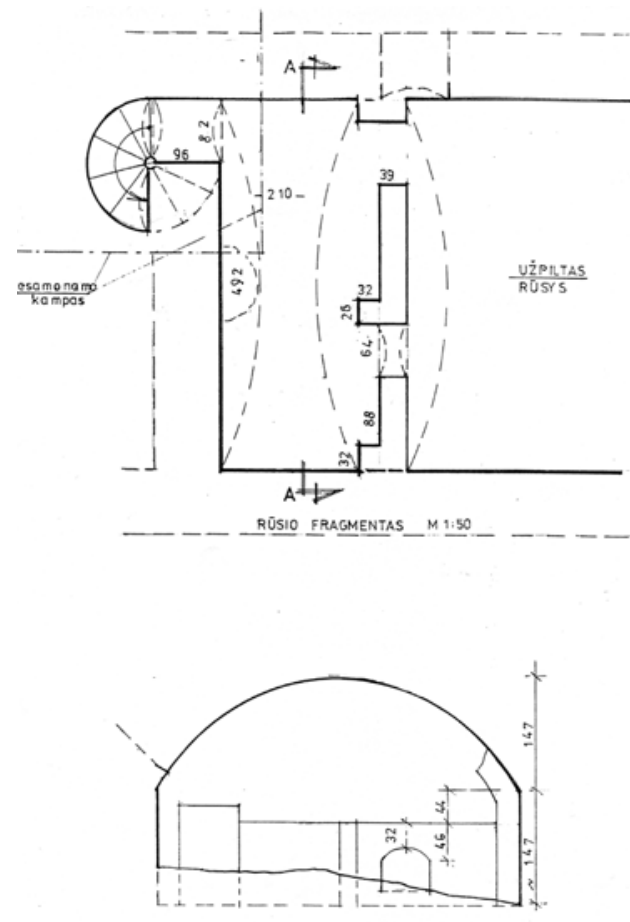

PJŨVIS-A A

9.

Raudondvario dvaro sodybos rūsio fragmento planas, pjūvis, in: Birutė Gudynaitè, Bijutiškio dvaro sodybos IP 437/At ir Raudondvario dvaro sodybos IP 910/At dviejų pastatų fiziniai tyrimai, l. 14

Plan of a detail of the cellar of the Raudondvaris Manor, cross-section

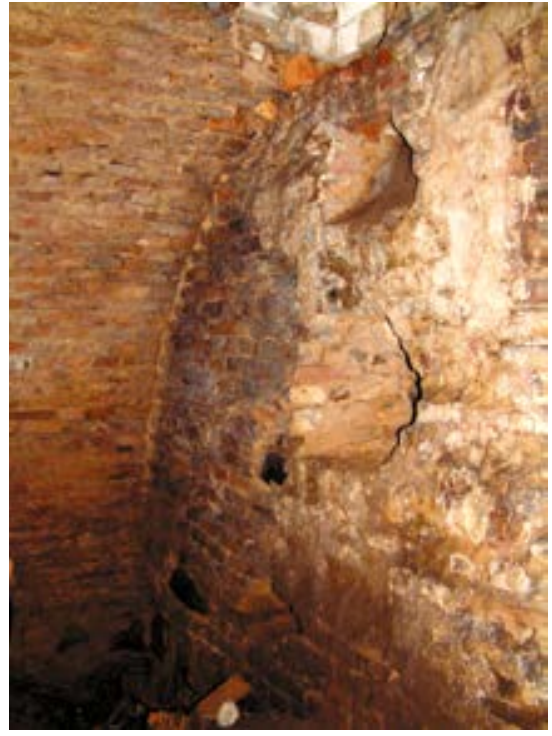

10

Raudondvario dvaro sodybos rūsys, Indrès

Kačinskaitès nuotrauka, 2002

Cellar of the Raudondvaris Manor, 2002

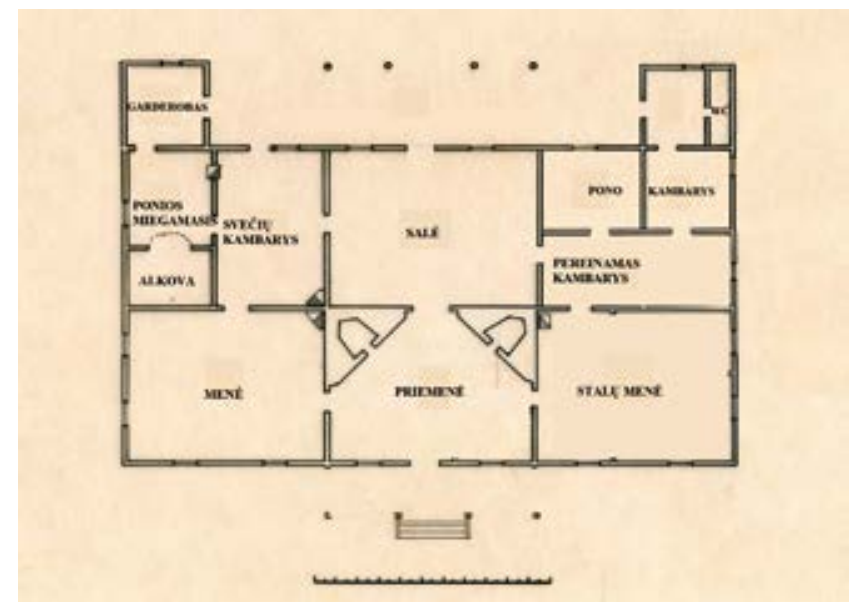

11.

Raudondvario dvaro sodybos dvarininko namo I a. plano schema, in: Dalè Puodžiukienè, Medinès ponu namu archtektūros raida Lietuvoje XVI a. vid. XIX a. vid., p. 51

Drawing of the ground-floor plan of the landowner's house of the Raudondvaris Manor 
pono kambarys, tualetas. Kairejje pastato dalyje buvo įrengta menė, o už jos - „ponios apartamentai“: svečiu kambarys, miegamasis su „alkova“ ir „garderobas“ (rūbinè) ${ }^{30}$ [11 il.]. Lodžija šiaurinėje pastato dalyje betarpiškai susieta su už namo ịveistu sodu. Toks pastato suplanavimas priskiriamas stambių bajorų rūmų su galerija - lodžija nugarinio fasado centre tipui, plitusiam XVIII a. viduryje ${ }^{31}$.

Ir nors barokini pastato vaizdą vèliau pakeitè klasicistinis, Raudondvario rūmai barokinę pastato plano struktūrą buvo išlaikę dar ankstyvuoju sovietmečiu, ji fiksuota 1957 m. plane [12 il.]. Klasicizmo laikotarpiu iš esmès pakito pastato architektūra, interpretavusi šio stiliaus madas: stogo forma iš mansardinės perdaryta ị pusvalminę, pastato šoninių fasadų centre suformuoti atviri prieangiai - portikai, kurių medinès kolonèlès rèmè dvišlaičius stogelius ${ }^{32}$. XIX a. - XX a. pradžioje didintas ir pastato tūris: pristatyti vieno aukšto vakarų ir rytų korpusai. Vakarų korpusas pastatytas apie 1907 m., jame ịrengtos pagalbinès patalpos ir šeimininkų vonių kambariai $^{33}$. Sovietmečiu pastatas paverstas daugiabučiu pakeičiant istorinị jo suplanavimą, pokyčių neišvengė ir pagrindinio korpuso bei priestatų architektūra [13 il.]. Puošnius rūmus šiuo metu mena tik centrinio korpuso dideli langai su langinèmis, mediniai supaprastintų formų prieangiai ir medinio profiliuoto karnizo fragmentai. Pakitęs pastato vaizdas nebepriminė rūmų architektūros, todèl toliau straipsnyje bus įvardijamas dvarininko namu.

Šalia pagrindinio dvaro sodybos pastato - rūmų - stambiose dvarų sodybose tradiciškai statytas ir lobynas. Dabartinès lietuvių kalbos žodynas nurodo, kad „Lobynas“ - tai kokių nors vertybių sankaupa, sukaupimo vieta $^{34}$. Lobynai perėmė povalušo, kuriais XVII a. vadinti dvarų sodybų pastatai, skirti saugoti ne tik brangiems daiktams, bet ir rakandams, grūdams, maisto produktams, funkciją, taip pat labai dažnai ir formą ${ }^{35}$. Raudondvario dvaro lobynas Inventoriuje apibūdintas gan trumpai: įeinant ị lobyną vienvèrès metalinėmis vinimis sukaltos dvigubos durys su vyriais ant kablių,

30 Dalè Puodžiukienè, Medinès ponu namu archtektūros raida Lietuvoje XVI a. vid. XIX a. vid., p. 51.

31 Ibid., p. 50.

32 Stasys Abramauskas, op. cit., 1. 6. Šiuo metu stogo forma valminè, manoma, pakeista sovietmečiu, stogą dengiant asbocementine danga.

33 Ibid., p. 4.

34 Dabartinès lietuvių kalbos žodynas, Vilnius: Vilniaus mokslo ir enciklopedijų leidykla, 1993, p. 373.

35 Dalė Puodžiukienė, „Dvaro sodybos pastatas povalušas: funkcija, forma ir tradicija“, p. 162. 


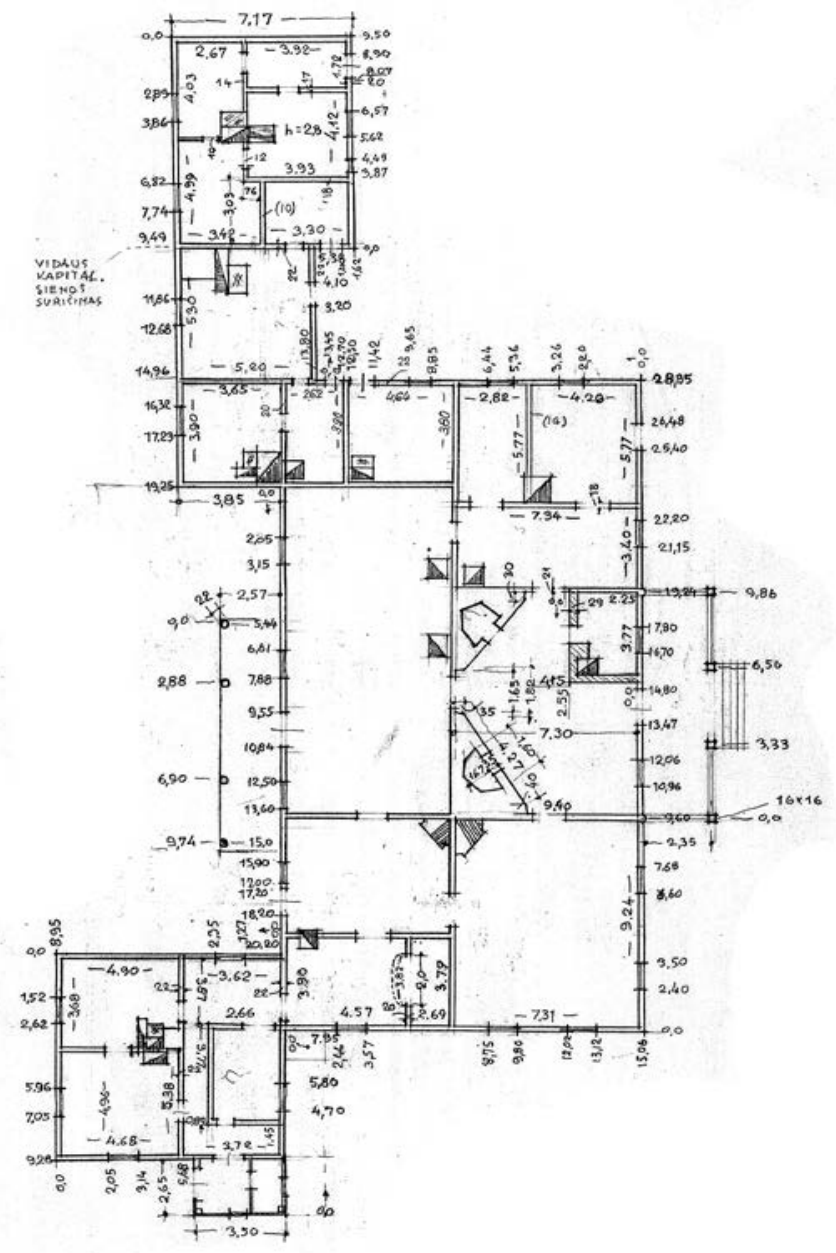

12.

Raudondvario dvaro sodybos dvarininko namo I a. plano schema, sud. V. Miliūkštis, KPCPB, brëžinys

Drawing of the ground-floor plan of the landowner's Nr. 2507 
vidine spyna bei „klamka“. Viduryje to lobyno - langas be stiklo su geležinèmis grotomis. Išẻjus iš lobyno ir pasisukus po dešine ranka link sodo - vienvèrès durys su vyriais ant kablių, „klamka“ ir laiptai, vedantys į antrą aukštą. Užlipus tais laiptais i galeriją - durys ị koplyčią vienvèrès su vyriais ant kablių ir vidine spyna su „klamka“. Tos koplyčios centre - du stiklo langai medyje su dvejomis vienvèrèmis langinèmis su vyriais ant metalinių kablių. Tas lobynas gontais dengtas ${ }^{36}$.

Po 1820 m. rekonstrukcijos, kurios data, manoma, buvo užfiksuota ant statinio vejjarodès, pastato vaizdas iš esmès pakito. Tai dviaukštis medinių rąstų statinys su rūsiu, juosiamas net dviejų galerijų: pirmame aukšte keraminių plytų mūro, arkine, su 3 arkomis kiekviename fasade, o antrajame - atvira medinių kolonèlių, remiančių antro aukšto stogelị [14, 15 il.]. Virš pagrindinio dviaukščio statinio tūrio, uždengto keturšlaičiu stogu, iškilo dviejų siaurèjančių tarpsnių medinis karkasinès konstrukcijos bokštelis. Jame - laikrodis ir varpas, virš jo - vèjo rodyklè su minèta $1820 \mathrm{~m}$. data ${ }^{37}$. Antro aukšto galerija juosė profiliuotas karnizas su dantukais, o bokštelio tarpsnius puošè klasicistines formas interpretuojantys piliastrai. Toks statinio vaizdas užfiksuotas Jano Bułhako 1930 m. nuotraukoje [16 il.]. 1968 m. sovietmečiu, numačius nykstantị pastatą restauruoti, V. Gromulas parengè lobyno istorinę pažymą, kurioje rẻmėsi vietinių žmonių prisiminimais, nurodžiusiais, kad pirmame aukšte ponų laikais buvo pilami grūdai, antrajame laikytos maisto atsargos: sūriai, sviestas, dešros, kumpiai, lašiniai, skilandžiai, o trečiame aukšte buvo įmontuotas laikrodis, kuris matydavosi iš keturių pusių. Bokšto varpu duodavo signalą, kada išeiti ị darbą, kada iš jo grižti, o ketvirtas aukštas, pats mažiausias, buvo naudojamas kaip stebèjimo punktas. Ponas ịlipęs i ji ji apžvelgdavo visus laukus ir juose dirbančius darbininkus ${ }^{38}$. Akivaizdu, kad istorinè lobyno paskirtis, pristačius bokštelį, pasipildè originaliomis, dvaro reikmėms skirtomis funkcijomis.

1968-1970 m. pagal Paminklu konservavimo instituto parengtą dokumentaciją pastatas buvo restauruotas ${ }^{39}$. Palyginti su $1930 \mathrm{~m}$. pastato nuotrauka, šiek tiek pasikeitė dviaukščio bokštelio formos ir kai kurios

36 Inventorius, 1. 430 (atvartas).

37 Alfonsas Lagunavičius, Gulbinų paukštininkystès tarybinis ūkis. Buv. dvaro lobyno esamos padèties fotofiksacija ir restauracijos sąmatos. Aiškinamasis raštas, Vilnius, 1968, in: KPCPB, f. 5, ap. 1, sv. 118, p. 1.

38 V. Gromulas, op. cit., 1. 2-3.

39 Alfonsas Lagunavičius, op. cit., p. 2. 


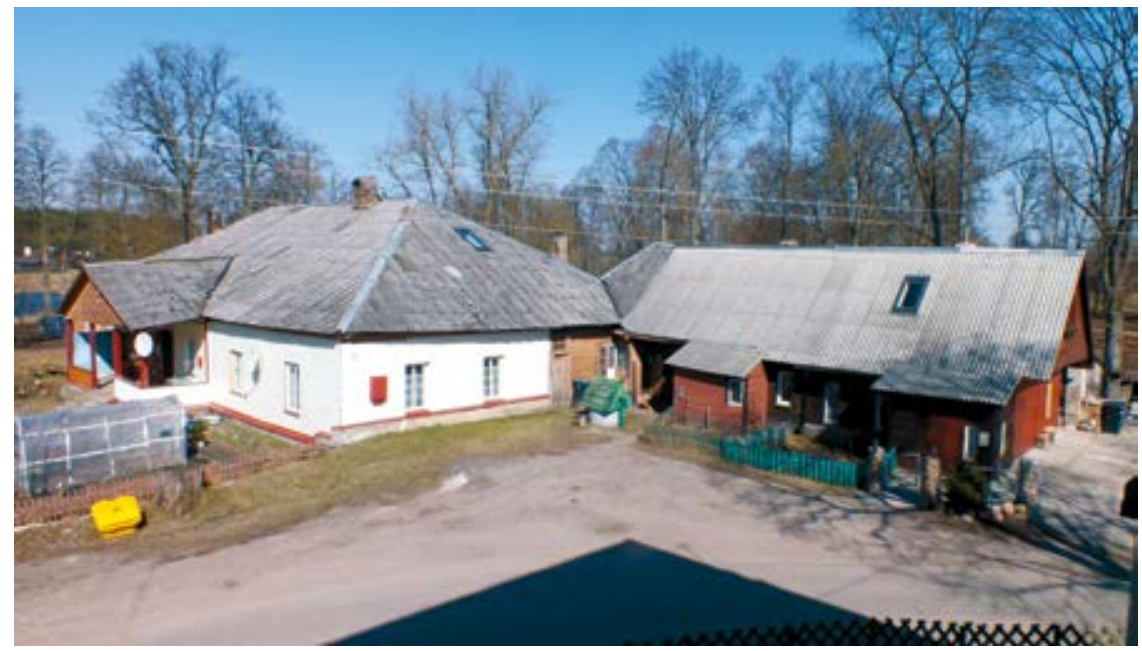

13.

Raudondvario dvaro sodybos dvarininko namas,

Landowner's house of the Raudondvaris Manor, 2018 Indrès Kačinskaitès nuotrauka, 2018

architektūrinès detalès - antrame aukšte ị langus buvo įdètos metalinès grotos, neišliko laikrodis ${ }^{40}$ [17, 18 il.]. 1988 m. Paminklų restauravimo projektavimo institutas parengè lobyno restauravimo darbo projektą, numatant pastatą pritaikyti muziejui, tačiau jis liko neigyvendintas, nes $1998 \mathrm{~m}$. gaisro metu sudegė statinio dviaukštis bokštelis, stogas bei viršutinė perdanga $^{41}$ [19 il.]. Po gaisro, ịvertinus pastato avarinę būklę, buvo pasiūlytos trys jo tvarkymo darbų kryptys: dvi atkuriant buvusi tūrị iki gaisro pagal jau parengtus minėtus restauracijos projektus ir trečioji - suteikiant pirminị 1764 m. vaizdą, užfiksuotą inventoriuje. Pasirinktas trečiasis tvarkybos darbų variantas. Pagal ji parengtas kur kas kuklesnis projektas, istorini pastatą pritaikęs gyvenamajam namui ${ }^{42}$ [20 il.]. Atsirado ir kur kas daugiau pokyčių, kuriuos lèmė pakitusi statinio funkcija: įstiklinta pastato pirmo aukšto galerijos erdvè, virš keturšlaičio stogo iškilo kaminas, pastato viduje irengtos naujos pertvaros. Nebuvo atkurtos antro tarpsnio puošnios klasicistinès detalès, fiksuotos ir po gaisro.

40 Romanas Firkovičius, op. cit., 1. 64.

41 Rasa Vasiliauskienė, 18-19 a. viet. reikšmès arch. paminklas buv. Raudondvario dvaro lobynas. Vilniaus r: Gulbinu tarybinis ūkis, AS dalis, Darbo projektas, Paminklų restauravimo projektavimo institutas, 1989, in: VRVA, f. 1019, ap. 12, b. 16525.

42 Jakovas Mendelevičius, Rasa Vasiliauskienè, Raudondvario (Gulbinu) buvusio dvaro AtV 801 lobynas. Vilniaus rajonas, Restauravimo techninis projektas, Vilnius: UAB „Elvora“, 2000. 


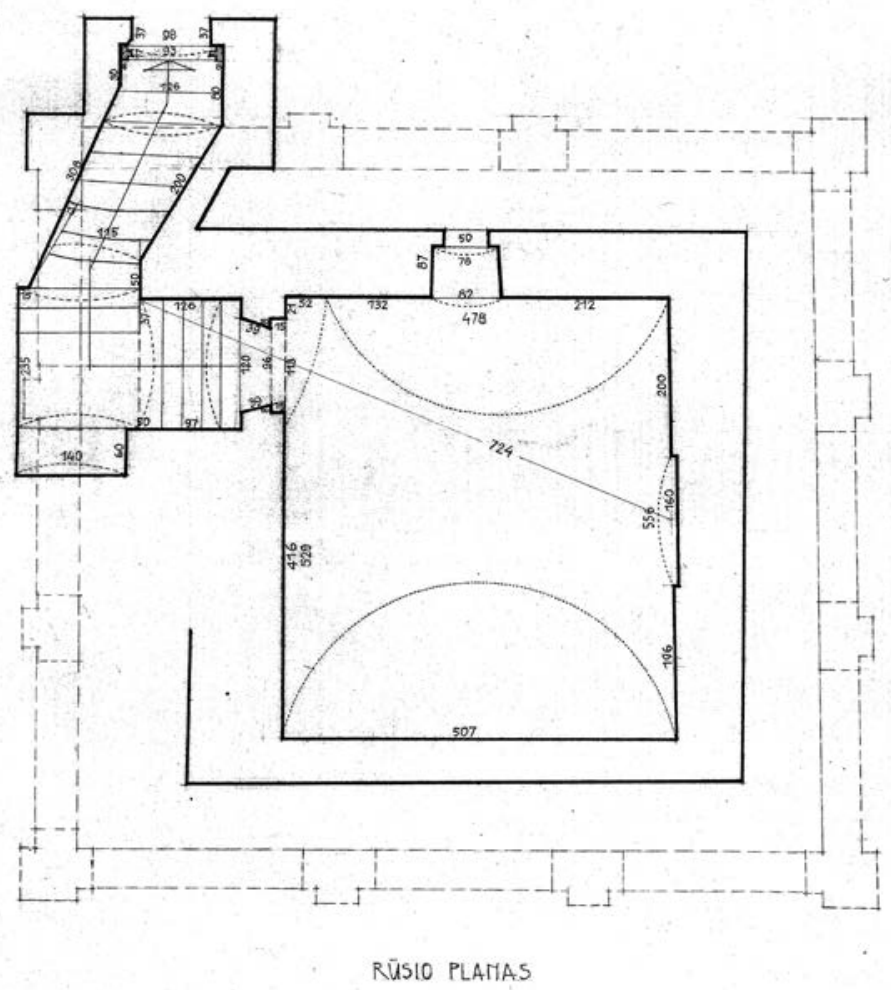

14.

Raudondvario dvaro sodybos lobyno rūsio planas, 1968, KPCPB, f. 5, ap. 1, s. v. 118, 1. 14
Cellar plan of the treasury of the Raudondvaris Manor, 1968 

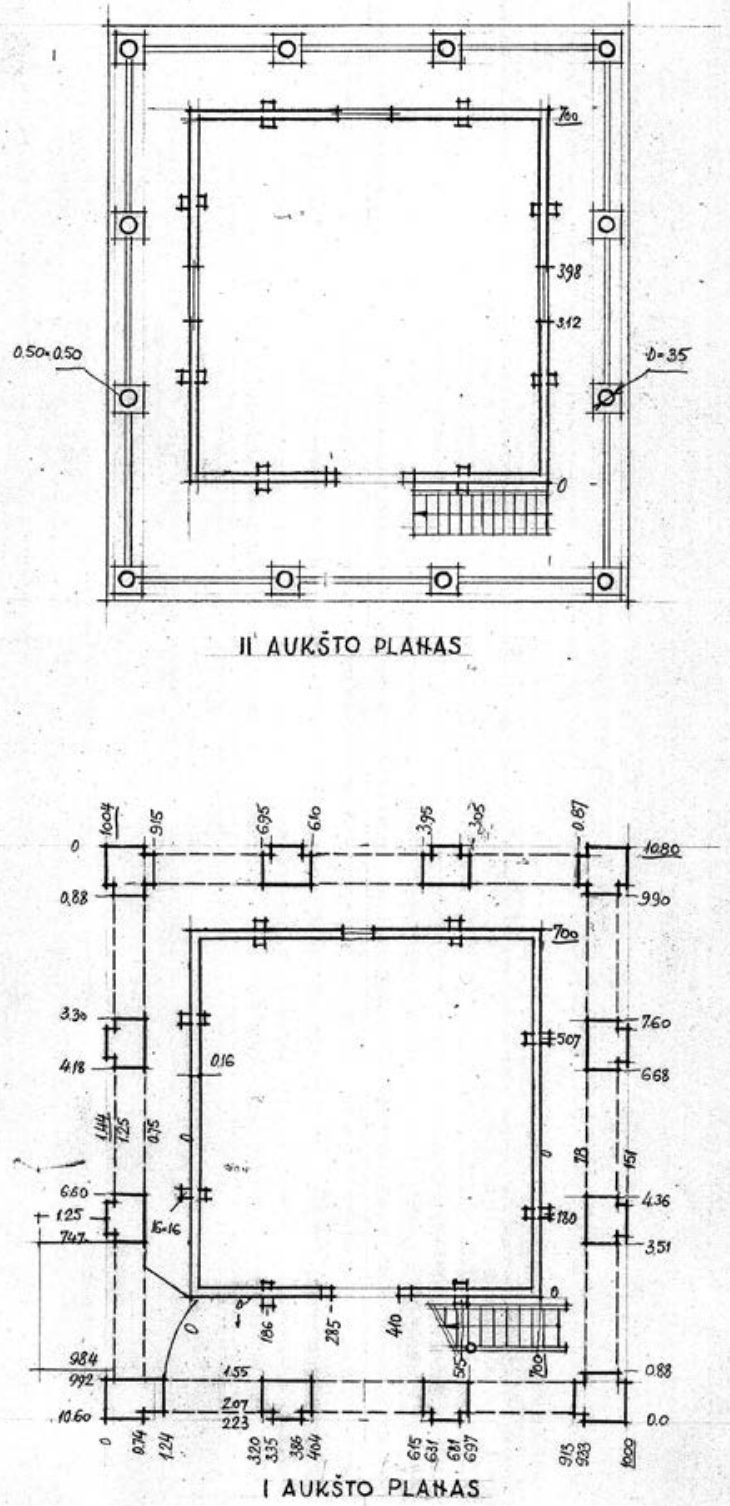

15 .

Raudondvario dvaro sodybos lobyno I ir II a. planai, sud. V. Saunoris, 1957, KPCPB, brèžinys Nr. 2508
Ground-floor and first-floor plans of the treasury of the Raudondvaris Manor, 1957 


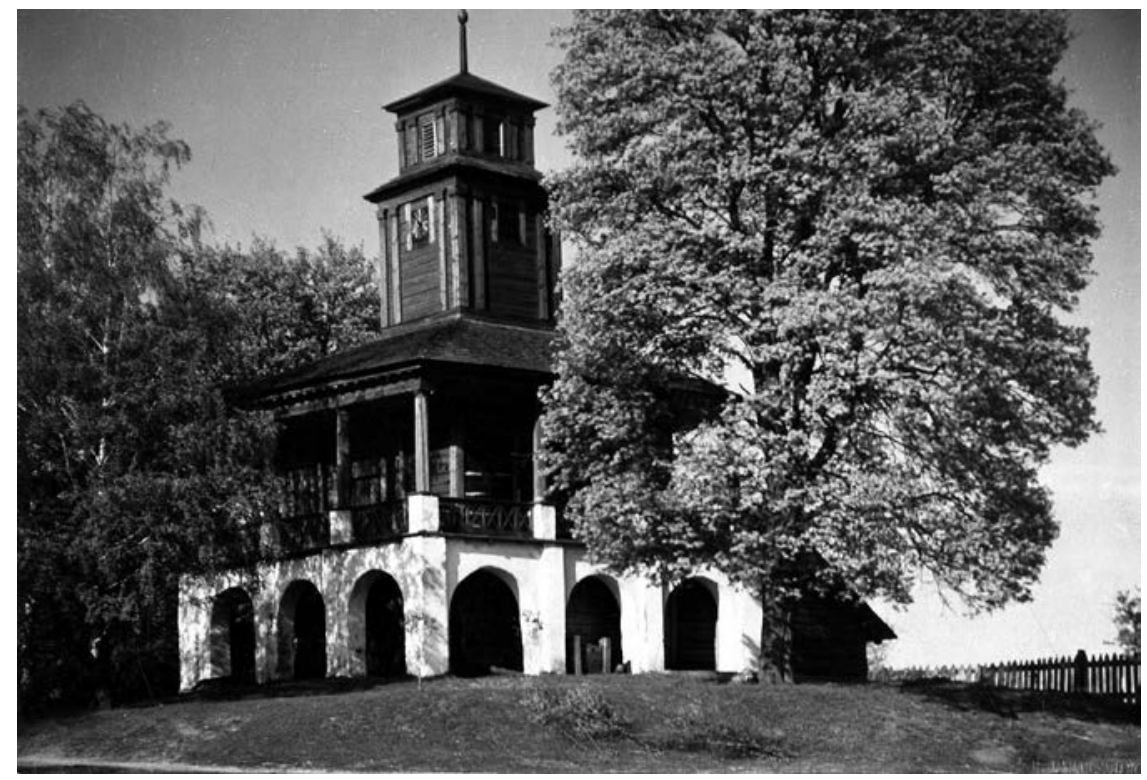

16.

Raudondvario dvaro lobynas, Jano Bułhako nuotrauka, 1930, LVIA, f. 1135, ap. 3, b. 419
Treasury of the Raudondvaris Manor, photo by Jan Bułhak, 1930

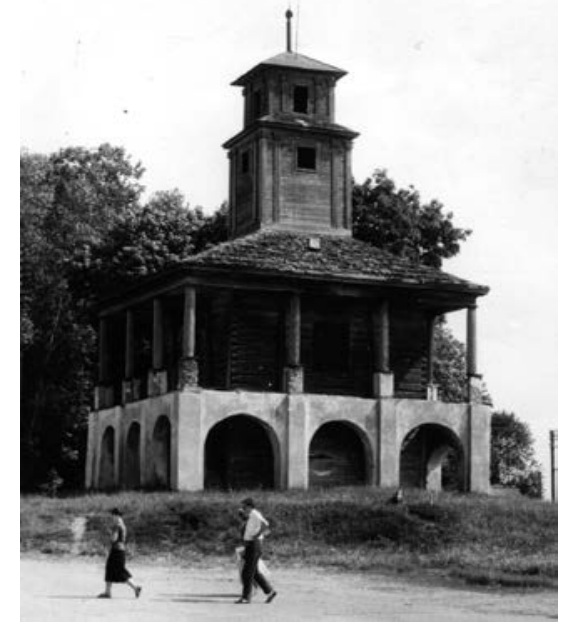

17.

Raudondvario dvaro lobynas, Indrės Kačinskaitės nuotrauka, 1993

Treasury of the Raudondvaris Manor, 1993

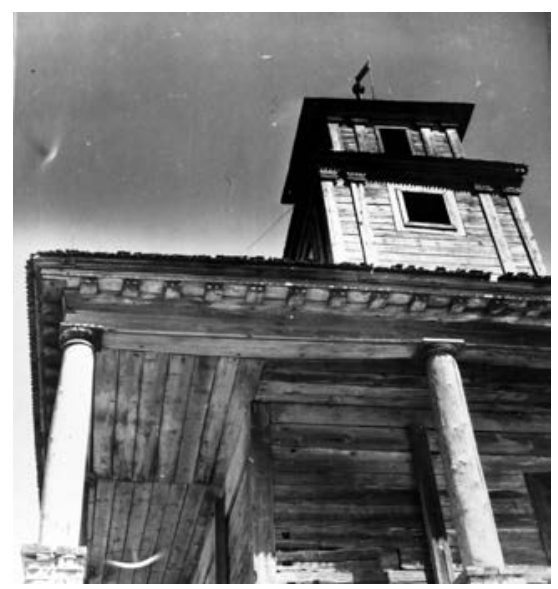

18.

Raudondvario dvaro lobynas, Gedimino Budreikos nuotrauka, 1987, KPCPB, f. 5, ap. 1, s. v. 3277.

Treasury of the Raudondvaris Manor, 1987 
2002 m. papildomai apžiūrejjus lobyno mūrus, paaiškèjo, kad iš ankstyvojo laikotarpio statybos etapo po pastatu esančiame rūsyje gerai išlikę plytų ir akmenų mūro sienos bei galais dètų plytų mūro cilindrinis skliautas. Iš dalies išlikęs ir rūsio laiptinukès eglute mūrytas skliautas bei mūrinių pakopų maršas su išorinėmis plytų ir akmenų sienutėmis. Statinio pirmo aukšto tinkuoto mūro atodangose fiksuoti ir vèlesnių mūrų fragmentai. Sprendžiant pagal plytas ir architektūrinius elementus bei tirtus analogus, lobyno ankstyvojo statybos etapo mūrai gali būti priskiriami XVII a. pradžios statybos laikotarpiui ${ }^{43}$. Remdamiesi šio tyrimo duomenimis, galime teigti, kad pirmo aukšto juosiančios plytų mūro galerijos pradinis statybos etapas taip pat gali būti priskirtas XVII a. pradžios statybos laikotarpiui. Išsiaiškinti, ar tikrai minètas rūsys jungėsi su dvarininko namu ir $2002 \mathrm{~m}$. atrastu rūsiu, nepavyko, nes 2019 m. ì jị patekti jau nebuvo galimybès.

\section{KITI PASTATAI}

Be pagrindiniu dvaro sodybos pastatu - dvarininko namo ir lobyno, centriniame kieme dar ir šiandien tebestovi du skirtingi tradicinės architektūros ùkiniai pastatai: galinio ir šoninio tipo svirnai. Pirmasis būdingas dvarų sodyboms - vienaaukštis stačiakampio plano, dviejų patalpų, su priesvirniu ir dviem uždaromis ji rẻminančiomis iškyšomis vakarų fasade, dengtas pusvalminès formos stogu, šiuo metu avarinès būklès [21, 22 il.]. Manoma, kad šis statinys, ivvardytas grūdų sandèliu, yra minimas ir $1764 \mathrm{~m}$. inventoriuje, kur trumpai pateiktas jo suplanavimas: įeinant i galeriją po dešine durys vedè $i$,,svirnelį“. Nuo to „svirnelio“ arti buvo durys ị kitą ,,svirną“, kurio viduryje - laiptai ị viršų ${ }^{44}$. Išlikusios pastato šoninès patalpèlès iškyšos abipus priesvirnio - yra būdingos klasicistiniams svirnams, todèl galëjo būti pristatytos XIX a. pirmoje pusejje. Antrasis svirnas - galinio tipo, medinių tašytų rąstų, su ịgilintu keturiomis medinèmis kolonèlemis paremtu priesvirniu rytiniame fasade, vienos patalpos, pusvalminiu stogu [23, 24 il.]. Jame išlikusios ir tradicinès svirnams dvigubos rombo ornamentu sukaltos durys, tiesa, šiuo metu savo dekoratyvia puse atsuktos į statinio vidų [25 il.]. Jo statybos data, manoma, jau XIX a. pirma pusè. 


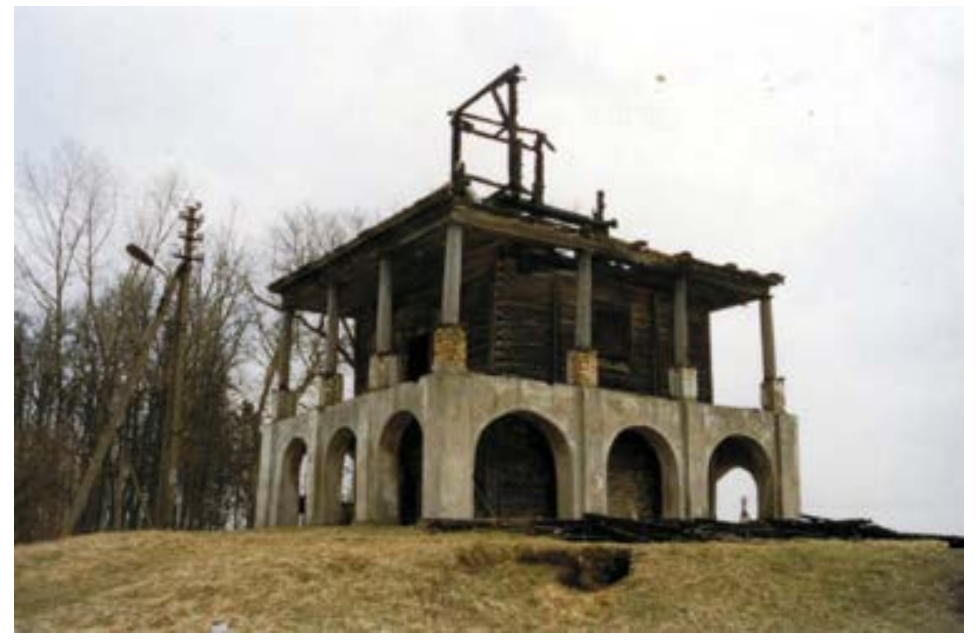

19.

Raudondvario dvaro lobynas, Indrès Kačinskaitès Treasury of the Raudondvaris Manor, 2000 nuotrauka, 2000

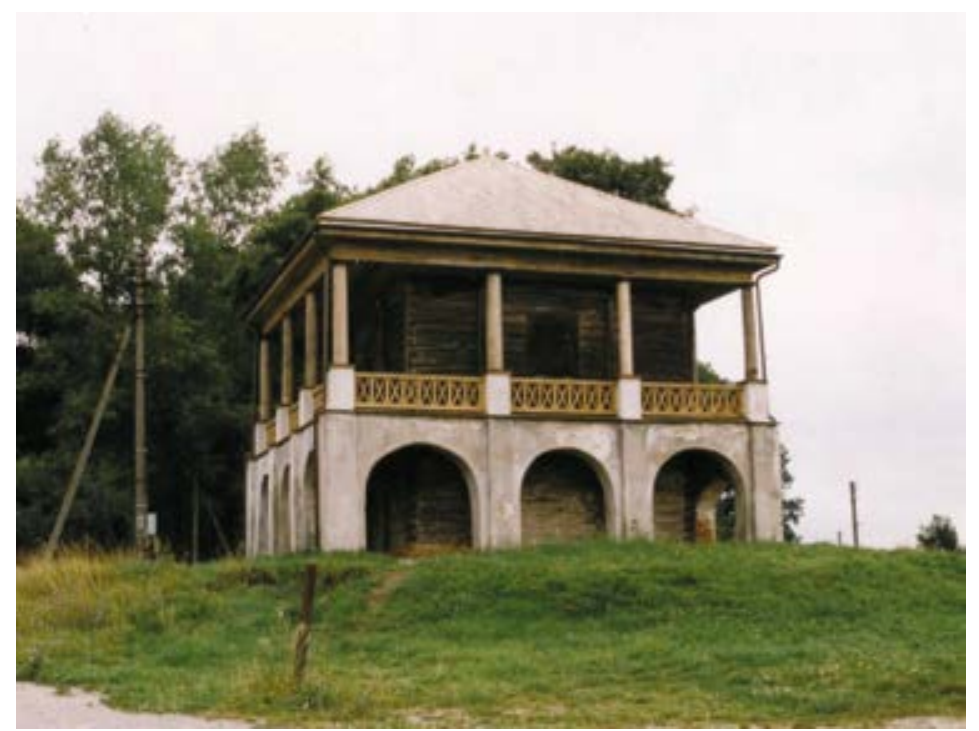

20.

Raudondvario dvaro lobynas, Indrès Kačinskaitès nuotrauka, 2005

Treasury of the Raudondvaris Manor, 2005 


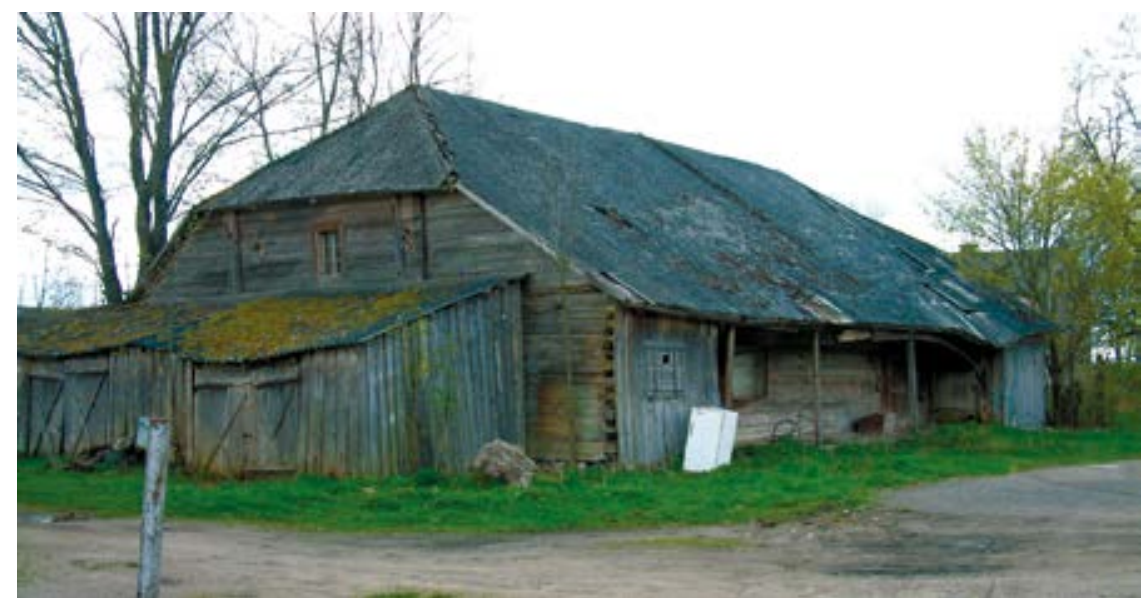

21.

Raudondvario dvaro sodybos pirmas svirnas, vakaru $\quad$ First granary of the Raudondvaris Manor, west fasadas, Indrès Kačinskaitès nuotrauka, 2018

façade, 2018

İdomi kito ūkinio sodybos centrinio kiemo pastato - arklidès genezè. Inventoriuje tarp svarbiausių dvaro pastatų, šalia rūmų, oficinos, rūsių ir lobyno, minima ir geroji arklidè, prie kurios iš abiejų pusių glaudèsi vežiminè ${ }^{45}$. Senasis Inventoriuje aprašomas pastatas neišlikęs, šiuo metu arklidėmis vadinamas (jame ir laikomi žirgai) keturių korpusų su uždaru kiemu akmens ir plytų mūro statinys ties įvažiavimu ị dvaro sodybos centrinị kiemą. Iddomu tai, kad tokio tūrio statinys šioje vietoje minimas ir Inventoriuje. Tai būta šiaudais dengto diendaržinio tvarto su arklide: „kvadratu pastatytas, su vidiniu kiemu, ị kurị vedè įvažiavimo vartai“. Abiejose tų vartų pusèse buvę dvi arklidès su vienvėriais įvažiavimo vartais. Minima, kad pastate buvo keturios kiaulidès vienvėrèmis durimis ${ }^{46}$. Toks statinys pažymėtas ir XIX a. pirmos pusès bei XIX a. pabaigos planuose, todèl, manoma, kad buvusio tvarto vietoje, kaip nurodo ir V. Abramauskas, 1895 m. pastatytas naujas artimo tūrio pirminiam diendaržiniam tvartui akmens ir plytų mūro pastatas ${ }^{47}$ [26 il.].

$1764 \mathrm{~m}$. inventoriuje įvardyti ir du centriniame kieme stovėję mediniai, neišlikę, gyvenamieji pastatai: oficina ir administratoriaus namas ${ }^{48}$. Manoma, vietoj vieno iš jų XIX a. pirmoje pusèje buvo pastatytas plytų

45 Ibid., 1. 431.

46 Ibid.

47 Nurodoma, kad 1895 m. statytos naujos akmens mūro arklidès ir karvidès; Stasys Abramauskas, op. cit., 1. 4.

48 Inventorius, 1. 431. 


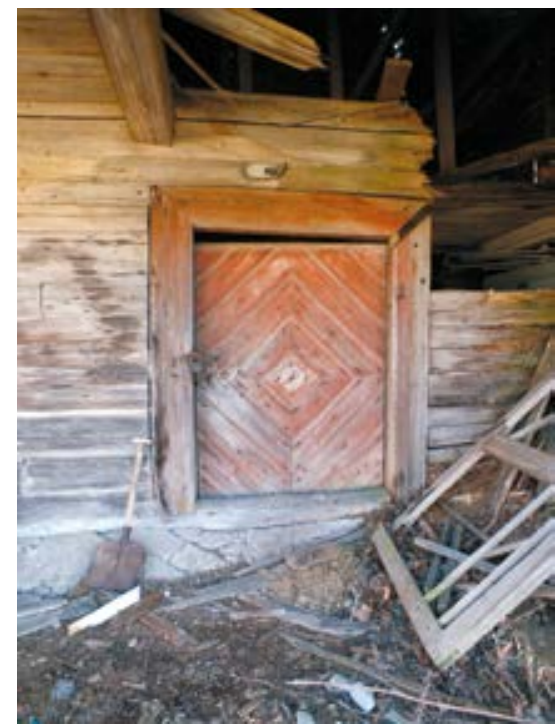

22.

Raudondvario dvaro

sodybos pirmas svirnas, vakarų fasado durys, Indrès Kačinskaitès nuotrauka, 2018

First granary of the Raudondvaris Manor, door of the west façade, 2018
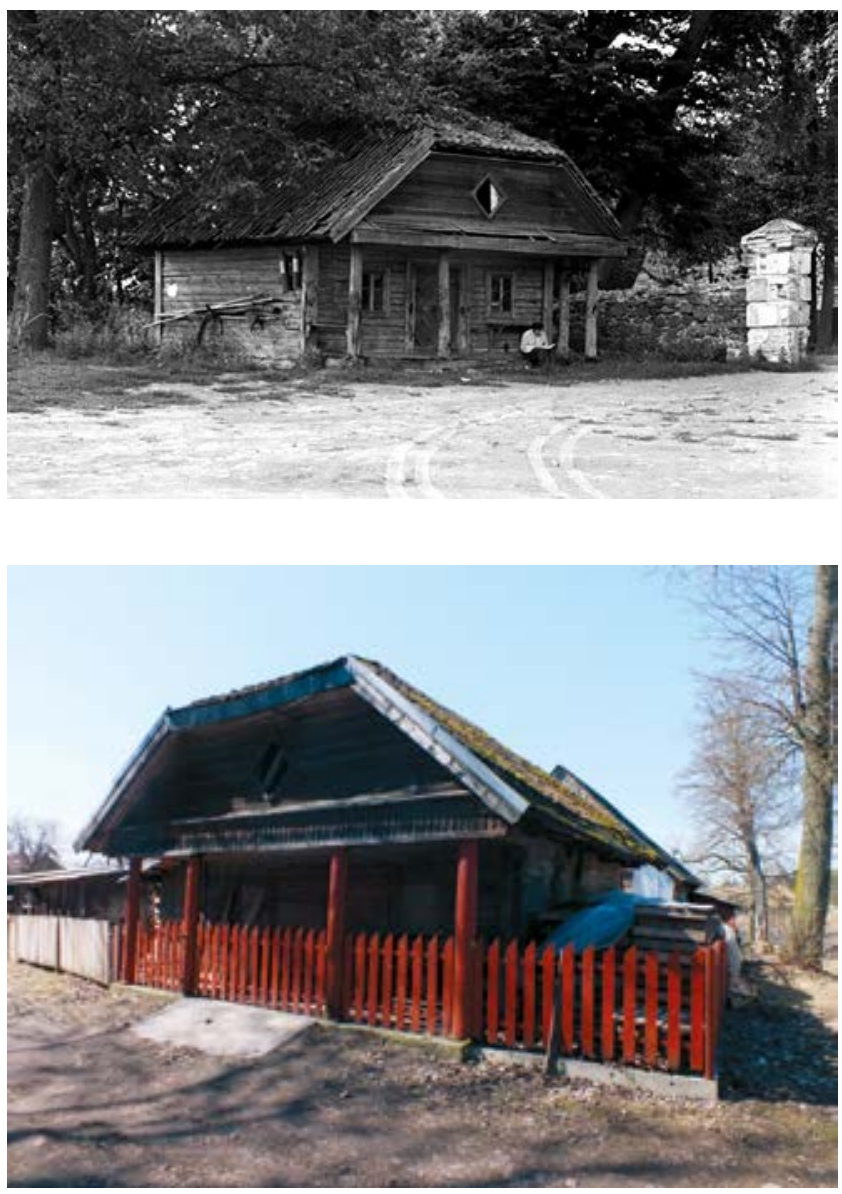

23.

Raudondvario dvaro sodybos antras svirnas, vakarų ir pietų fasadai, V. Miliūkščio nuotrauka, 1957, KPCPB, f. 41, architektūra 2756

Second granary of the Raudondvaris Manor, west and south façades, 1957
24.

Raudondvario dvaro sodybos antras svirnas, vakarų ir pietų fasadai, Indrès Kačinskaitès nuotrauka, 2018

Second granary of the Raudondvaris Manor, west and south façades, 2018 
mūro kompaktiško tūrio vieno aukšto pusvalminiu stogu pastatas, šiandien tapęs gyvenamuoju namu ir iš esmès pakeitęs architektūrinę išraišką. Iš ūkinio kiemo pastatų, rytuose besiribojusių su centrinio kiemo erdve ir gausiai pažymètų XIX a. pirmos pusès plane, išlikęs tik kluonas [27 il.]. Statinys buvęs tradicinės architektūros: vieno aukšto sienas sudarė akmens mūro stulpai su dar žymia XIX a. pirmai pusei būdinga akmenukų kamša. Šiuo metu vidaus konstrukcija pakeista pastatą pritaikius maniežui. Taip pat žinoma, kad $1886 \mathrm{~m}$. dvaro sodyboje pastatyti du vienaaukščiai akmens mūro pastatai ${ }^{49}$. Vienas iš jų - akmens mūro, pakitusio tūrio ir funkcijos ūkinis pastatas tebestovi ties vakariniu kiemo perimetru [28 il.].

Buvusi gausi pastatais dvaro gamybinė dalis telkèsi ties upeliu, Raudonojo Dvaro ežero pietine ir vakarine pakrantėmis. Inventoriuje minimas einant link skalbyklos dešinejje ant ežero kranto bestovintis bravoro pastatas, skalbyklos būta sujungtos su kalve po vienu stogu. Vandens malūnas šalia patvenkto upelio ịvardytas kaip blogos būklès, o šalia jo paminètas stovėjęs ir kur kas geriau išlikęs vẻjo malūnas bei plytinè $\dot{j}^{50}$. Degtinės varykla, plytinė, vandens malūnas įvardyti $1804 \mathrm{~m}$. dokumente ${ }^{51}$, pažymėti ir XIX a. pradžios plane [žr. 1 il.]. XX a. pradžioje vandens malūnas su patvanka plane jau nenurodomas, sovietmečiu sunyko ir istorinė gamybinė dalis [̌̌r. 3,4 il.].

\section{DVARO SODYBOS SODAS-PARKAS}

$1764 \mathrm{~m}$. inventoriuje sodas neminimas, o $1804 \mathrm{~m}$. Raudondvario dvaro aprašyme, šalia kitų statinių, paminètas ir vaismedžių sodas (ogrod), tačiau išsamesnių žinių apie jị nesuteikiama ${ }^{52}$. Žinoma, kad jau XVII a. pirmoje pusejje rekreacinė dvarų sodụ programa pasireiškẻ kaip estetinių ir vartotojišku poreikių derinimas. Detalesniuose inventoriuose minimi vadinamieji produkciniai daržai ir sodai sodinti i i ivairaus dydžio stačiakampius sklypus (kvaterus), o juose augo daržovės, kopūstai, slyvos, vyšnios, obelys. Itališkas sodas, kuriame, pagal J. K. Haurą, turèjo stovèti „fontanas, grota, altanos ir oranžerija“, fiksuotas tik stambiose didikų elito rezidencijose (pvz., Myre, Koreličiuose, Verkiuose). Kuklesniame istoriniame sode pagrindiniai

49 Ibid.

50 Inventorius, 1.432 (atvartas).

51 Vilniaus gubernijos matininko statistinès žinios, 1804, 1. 6.

52 Ibid. Pastaba: sodu ịvardijama pirminė geometrinio suplanavimo parko dalis, parku - visa istorinio želdyno kompozicija su vakarine kraštovaizdine dalimi. 


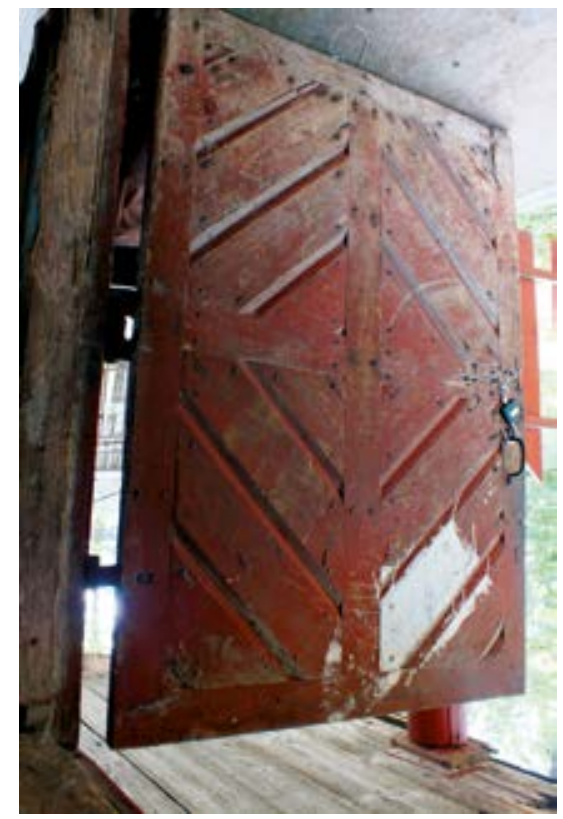

25.

Raudondvario dvaro sodybos antro svirno durys, Indrès Kačinskaitès nuotrauka, 2018

Door of the second granary of the Raudondvaris Manor, 2018

struktūriniai elementai buvo kvaterai, apsodinti medžių, krūmų eilèmis ar alëjomis $^{53}$. Raudondvaryje, sprendžiant pagal XIX a. pradžios planą, už dvarininko namo buvo ịrengti du tokie kvaterai, kuriuos skyrė centrinis takas - alèja, vedanti link sakralinio statinio [žr. 1 il.]. Žinių apie XIX a. antros pusės Raudondvario sodą suteikia $1891 \mathrm{~m}$. planas, kuriame už dvarininko namo pavaizduotas kvadratas - parteras (?), skaidomas ịstrižų takų ar alèjų (?) tinklo su akcentuota aikštele centre. Už jo šiaurès kryptimi per XIX a. pradžioje buvusią kluonų teritoriją toliau pratęstas takas - alejja (?), sutapusi su visos sodybos kompozicine ašimi [žr. 2 il.]. Šiandien išlikusioje sodo struktūroje dominuoja tik tiesių mažalapių liepų alejjų fragmentai, kur yra ir vaismedžių sodo likučių [29 il.]. Centrinị kiemą nuo sodo erdvės skyrusi akmens mūro tvora su klasicistinių formų vartų stulpais, kurios fragmentas užfiksuotas 1957 m. nuotraukoje ir sodybos plane, neišlikusi [žr. 4, 6 il.]. Priešais dvarininko namo pietini kiemo fasadą šiuo metu veši sulaukèjęs želdynių masyvas su išsiskiriančiais keliais brandžiais sidabriniais klevais ir pocūgėmis - buvusio parterio žymès. 


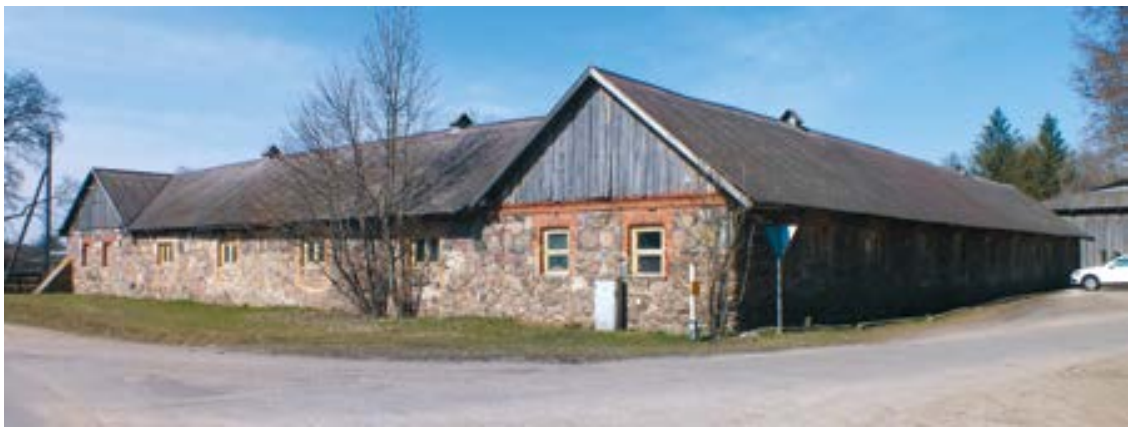

26.

Raudondvario dvaro sodybos arklidè, pietu ir rytu fasadai, Indrès Kačinskaitès nuotrauka, 2018
Stables of the Raudondvaris Manor, south and east façades, 2018

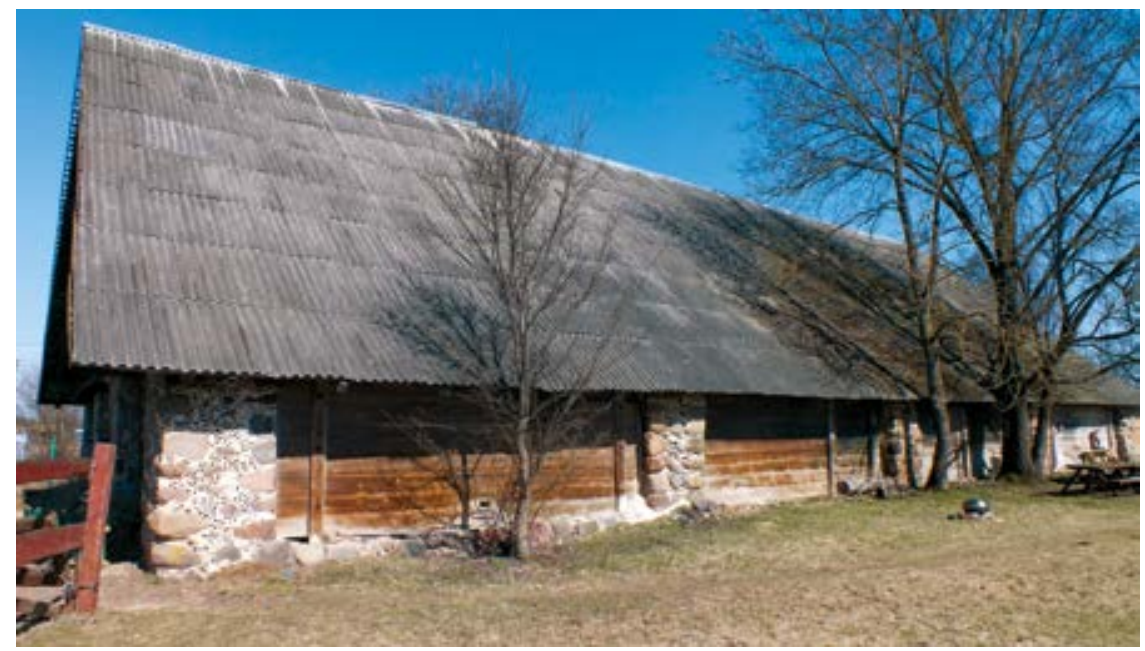

27.

Raudondvario dvaro sodybos kluonas, pietu fasadas, Indrès Kačinskaitès nuotrauka, 2018

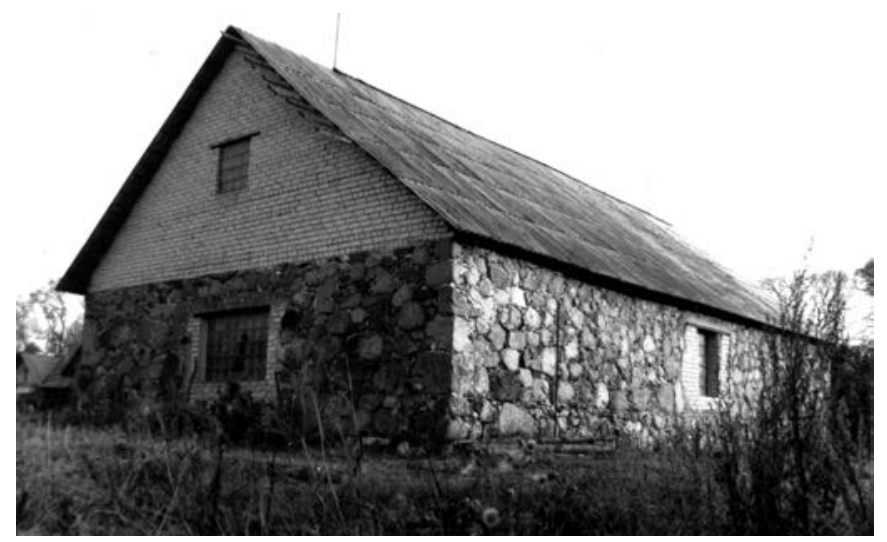

Barn of the Raudondvaris Manor, south façade, 2018
28.

Raudondvario dvaro sodybos ūkinis pastatas, vakarų ir šiaurès fasadai, Indrès Kačinskaitès nuotrauka, 1993

Auxiliary building of the Raudondvaris Manor, west and north façades, 1993 
Išsamesnis XX a. pirmos pusès istorinio sodo vaizdas paaiškejja susipažinus su S. Abramausko 1957 m. parengtu aprašymu:

Principinė parko išplanavimo schema yra geometrinè. Ant gyvenamojo namo šiaurinio portiko ašies randasi apie $5 \mathrm{~m}$ pločio tankiai liepomis apsodinta alejja. Jai lygiagrečiai abipus eina išilgai dar dvi kraštinės alejjos. Viduriniosios alëjos šiauriniame gale ant neaukšto mūrinio cokolio stovejjo nedidelè medinė koplyčia, kuri $1955 \mathrm{~m}$. buvusi nugriauta. Ties koplyčia eina skersine statmena kryptimi skiriamoji alèja, jungianti abi paminètas kraštines. Susidaro alëjomis apsupti 2 uždari stačiakampiai simetriški plotai, buvę žolėmis užsèti parterai. ${ }^{54}$

Už paminètų parterų prasideda ūkinis vaismedžių sodas. Sodas irgi iš rytinės ir šiaurinès pusių apsuptas tokio pat tipo tankiai užsodintų medžių alèjomis. < ... > Sode seniau stovejjusi altana, kuriai vieta buvo parinkta ant bažnyčios bei koplyčios kompozicinès ašies ${ }^{55}$

Tiksli minètos altanos vieta istoriniuose planuose nėra pažymėta, todèl išlieka neaišku, apie kokią bažnyčią šiame aprašyme užsimenama, nes nèra duomenų, kad Jadvygiškių kaime yra stovėjusi bažnyčia. Parko-sodo planas turėjo aiškiai išreikštą kompozicinę ašĭ, kurią išryškino net du sakraliniai statiniai. Vieno iš jų - koplyčios vieta užfiksuota XIX a. pradžios plane ir 1957 m. nuotraukoje [žr. 1, 30 il.].

Tiriant išlikusią sodybos istorinio želdyno struktūrą, tikru netikètumu tapo kraštovaizdinè dalis vakarinėje Raudonojo Dvaro ežero pakrantèje, profesonaliai prijungta prie senosios dalies. Jeigu istorinėje geometrinėje dalyje dominavo centrinė kompozicinè planavimo ašis, tai čia ji vizualinè, nuo dvarininko namo orientuota link kalvelès prie šiaurinio Raudonojo Dvaro ežero kranto [žr. 29, 32 il.]. Analizuojant istorinę sodo-parko kompoziciją, išaiškejja, kad i šią kalvą vedè ne tik plastiškų formų rytinės ežero pakrantès takas, apsuptas spygliuočių ir lapuočių medžių grupių ar pavienių medžių, bet ir šiaurinė reguliaraus suplanavimo sodo alèja [žr. 3, 4 il.]. Šiuo metu ši kalva apaugusi pušimis, jos detalesni tyrimai neatlikti, tačiau ap̌̌iūrèjus teritoriją, akivaizdu, joje buvusi ir statinio vieta, galbūt dar vienas parko kompozicijos akcentas - tolima pavėsinè ar altana. Sprendžiant pagal medžiú brandą, ši dalis galètų būti priskirta ir XX a. pirmai pusei. 


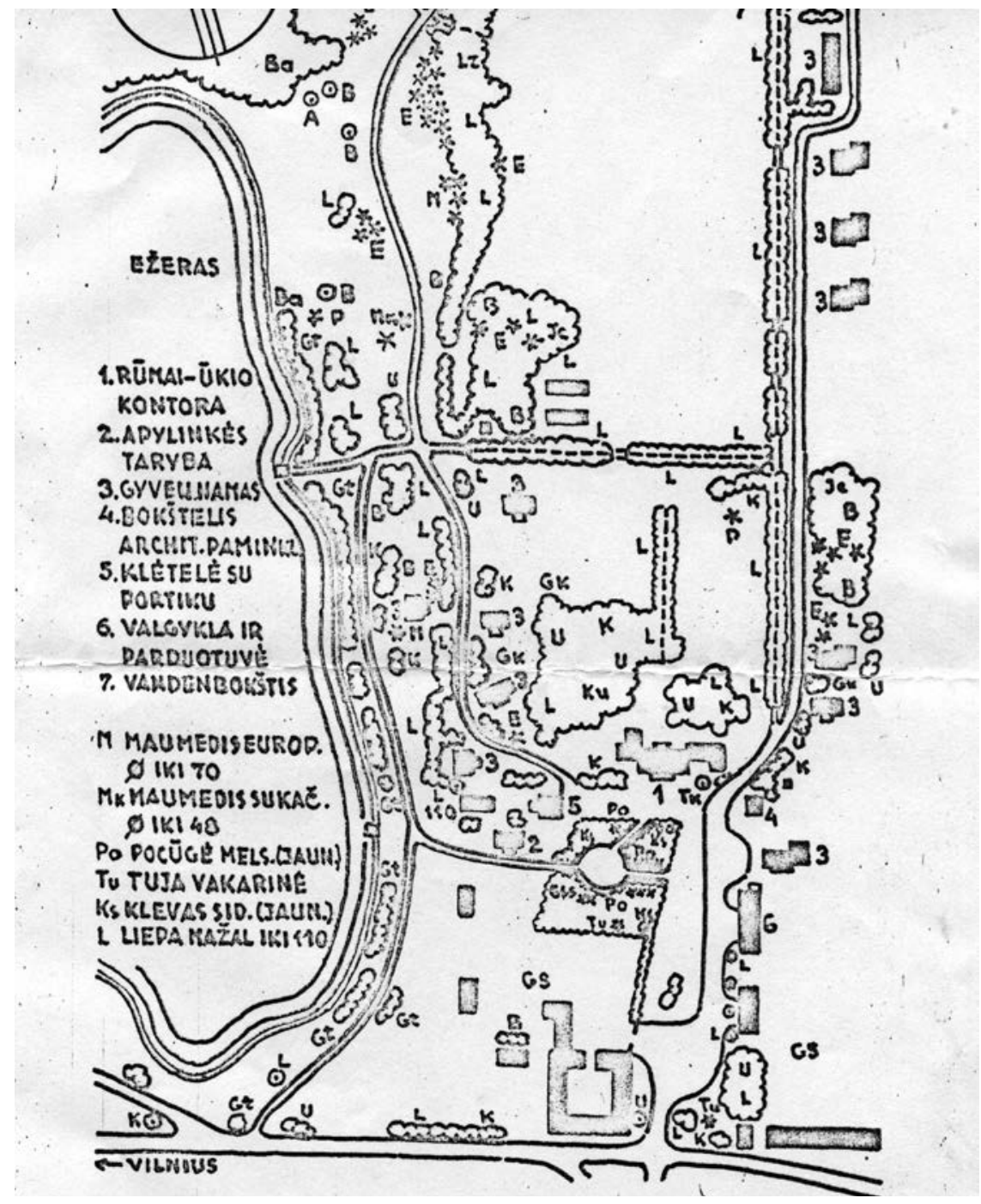

29.

Raudondvario dvaro sodybos parko schema, Lietuvos Drawing of the Raudondvaris Manor park, 1983 TSR valstybinis gamtos apsaugos komitetas, Vilniaus rajono parko pasas, 1983 


\section{A. PIRMOS PUSĖS PIEŠINYS. RAUDONDVARIO DVARO SODYBA (?)}

Dar praeito šimtmečio pabaigoje viename iš Vilniaus antikvariatu buvo parduodamas XIX a. pradžios paveikslas, vaizduojantis dvaro sodybą [33 il.]. Tiksliai nebuvo žinomas nei paveikslo autorius, nei nupieštas objektas. Domino ne rasto kūrinio profesionalumas, bet jame perteiktas provincialaus medinio dvarelio vaizdas, galimos sąsajos su šiandieniniu Lietuvos dvarų paveldu.

Piešinyje pateikta dvaro sodybos centrinès dalies suplanavimo struktūra yra tradicinè stambiam dvarui su dominuojančia pagrindine kiemo erdve, jungiančia ịvairios funkcinès paskirties statinius, želdynų elementus ị vieną visumą. Kaip ir Raudondvario dvaro sodyboje, piešinio centrą užima erdvus kiemas su apskritų formų gèlynu viduryje $\mathrm{e}^{56}$, jo kiemo perimetru - užstatymas, kur dominuoja mediniai vienaaukščiai pastatai. Išlikusių Raudondvario dvaro sodybos statinių: dvarininko namo, lobyno ir dviejų svirnų vietos atitinka piešinyje pateiktą pastatų kompoziciją. Jeigu centrinis pastatas - namas pavaizduotas itin utilitarus, nepasižymintis didesne architektūrine raiška, tai ūkinių pastatų - svirnų tipologinè ịvairovè bei ansamblio kompozicija artima Raudondvariui. Piešinyje užfiksuoti du statiniai, savo architektūra identiški šiandien išlikusiems, - tai lobynas kiemo gilumoje ir vieno aukšto galinio tipo medinis svirnas su keturių stilizuotų kolonų priesvirniu. Antrasis svirnas nupieštas ne vieno (koks yra šiandien), bet dviejų aukštų. Kompleksiškai išlikusių, senają XVII a. susiformavusią struktūrą atspindinčių medinių dvarų sodybų Lietuvoje žinoma tik keletas, o pavaizduotas piešinio gilumoje bokštinio tipo dviejų aukštų statinys, apjuostas galerijos, sietinas tik su vienu tokios raiškios architektūros pastatu - Raudondvario lobynu, todèl darytina prielaida, kad piešinyje pavaizduotas Raudondvario dvaro sodybos XIX a. pirmos pusès vaizdas. Jeigu ši prielaida ir liktų tik hipotetine, pasitvirtintų teiginys, kad toks dvaro sodybos centrinio kiemo suplanavimas, pastatų architektūra buvo tradiciniai mūsų kraštui. 


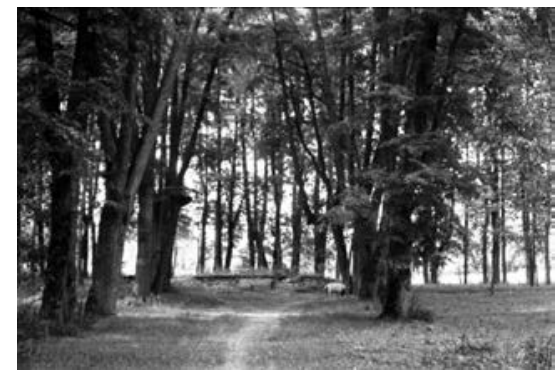

30.

Raudondvario dvaro sodybos parko centriné alèja, V. Miliūkščio nuotrauka, 1957, KPCPB,

f. 41 , architektūra 2756

Central alley of the

Raudondvaris Manor park, 1957

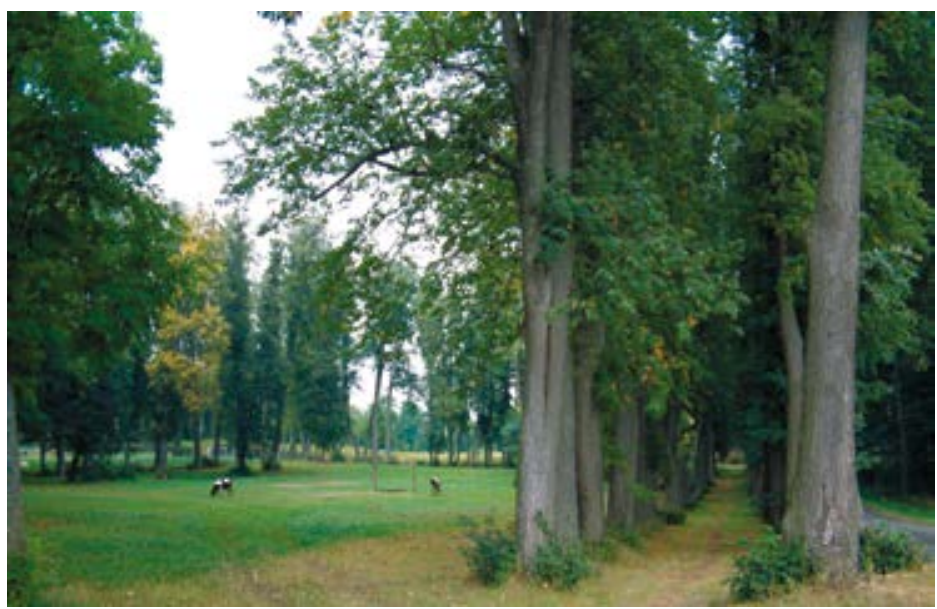

31.

Raudondvario dvaro sodybos parko alèjos, Indrès Kačinskaitès nuotrauka, 2002

Alleys of the Raudondvaris Manor park, 2002

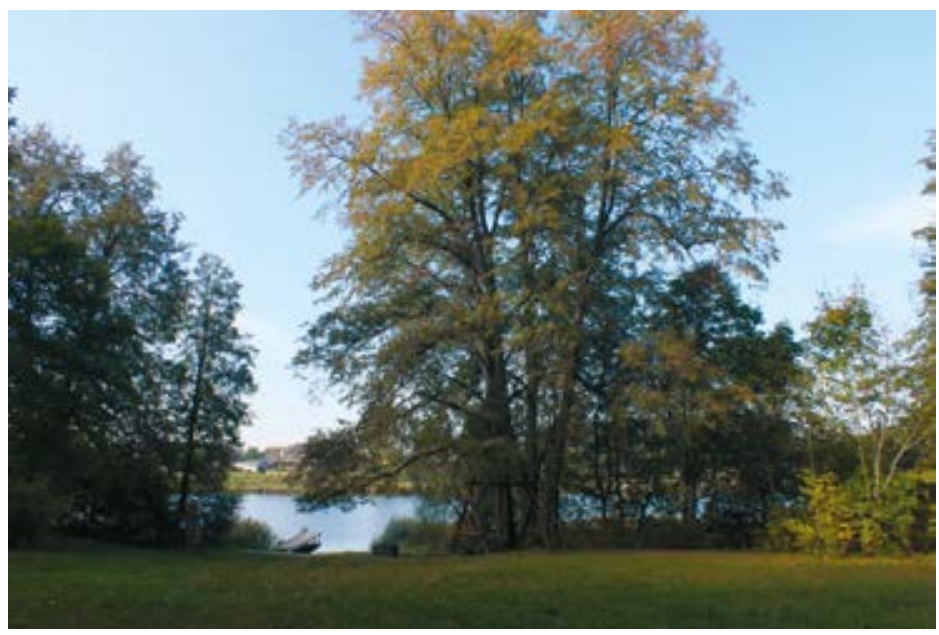

32.

Raudondvario dvaro sodybos parko kraštovaizdinė dalis, Indrès Kačinskaitès nuotrauka, 2018
Landscaped part of the Raudondvaris Manor park, 2018 


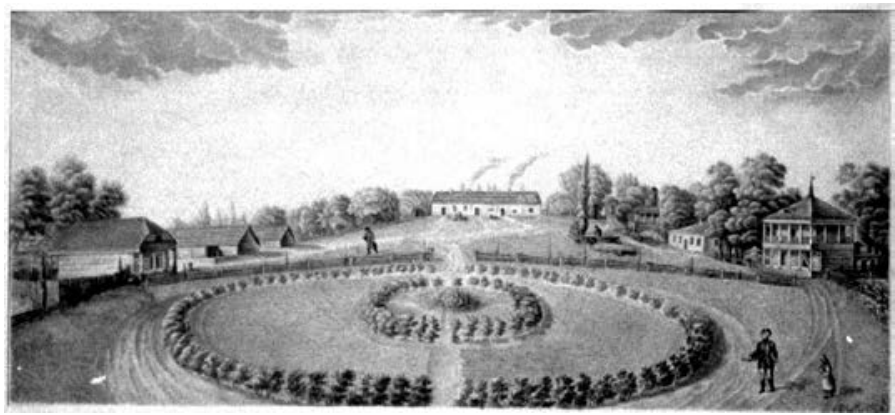

33.

Dvaro sodybos centrinio kiemo vaizdas, piešinys, XIX a. I p. (?), nežinomas autorius

View of the central courtyard, drawing. $1^{\text {st }}$ half of $19^{\text {th }} \mathrm{c}$.

\section{DVARO SODYBA ŠIANDIEN}

Itin spartūs pokyčiai šiandieninëje visuomenëje akivaizdžiai keičia ir sovietmečiu ignoruotą medinį dvarų paveldą. Vilniaus miestas plečiasi, i savo urbanistini audini ịtraukdamas vis didesnes buvusias priemiesčio teritorijas, turtingas buvusiomis dvarų sodybomis. Ne tik iš esmės kinta apie jas šimtmečius formavęsis autentiškas kraštovaizdis, bet skiriami sklypai naujoms statyboms jau intensyviai transformuoja ir pačių istorinių dvaru sodybų vaizdą. Privatizuotų Raudondvario dvaro sodybos pastatų savininkų gausa, jų interesų ịvairovė nebuvo palanki šiam kultūros paveldo objektui, neįstengta suvaldyti augančių jų poreikių gausos. Ryškūs kontrastai atsiveria sodybos centriniame kieme: dalies istorinių pastatų formos „modernizuotos“, pritaikant naujiems poreikiams, aplink juos suformuotos valdos aptvertos įvairiomis tvoromis, o, pavyzdžiui, šalia stovintis medinis dvaro svirnas jau daugelį metų nyksta nenaudojamas [34 il.]. Itin svarbią dvaro sodybos istorinei struktūrai, kompozicijai suvokti XVII a. reliktinio centrinio kiemo erdvę transformavo stambaus tūrio utilitarių formų ūkinis pastatas. Iš esmès pasikeitė ir Raudondvario dvaro sodybos siluetas, praturtinęs Vilniaus-Molètu kelio panoramą parko masyvu su dominavusiu lobyno bokštu tolumoje. Dvaro sodybai teko antraplanis vaidmuo, XX a. pabaigoje Vilniaus-Molètų kelio dešnëje pusėje, Raudonojo Dvaro ežero kitame, vakariniame krante, pastačius maitinimo ir poilsio paslaugų kompleksą (šiuo metu veikia restoranas „HBH 


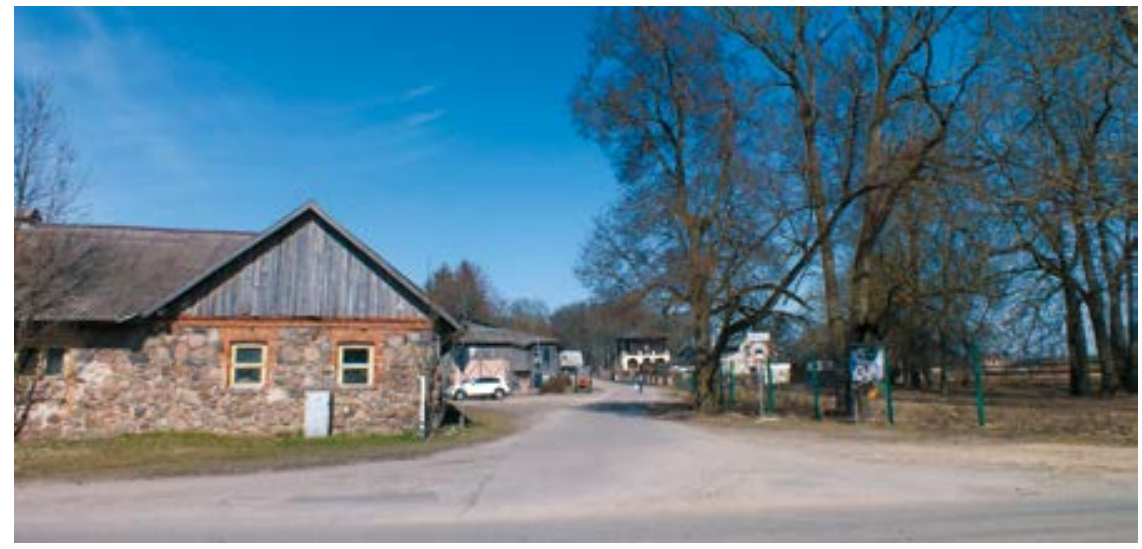

34.

Raudondvario dvaro sodybos centrinio kiemo vaizdas iš pietų pusès, Indrès Kačinskaitès nuotrauka, 2018
View of the central courtyard from the south side, 2018

Vilnius“), „imituojantį““ etnoarchitektūrines formas ir siūlantị sumodernintą paveldo sampratą vartotojui. 400 metų istorijos raidą skaičiuojanti Raudondvario dvaro sodyba tapo tik sparčiai besikeičiančia priemiestine teritorija. Prarasta galimybė išsaugoti istorini dvaro vaizdą, reprezentuojanti autentišką, o ne butaforinę medinę dvarų kultūrą. Šiandien dvaro sodyba, nors ir sparčiai besikeičianti, dar traukia lankytojus, besidominčius dvarų paveldu.

\section{IŠVADOS}

1. Raudondvario dvaro sodyba priskiriama prie seniausių medinių dvarų sodybų Lietuvoje, atspindinčių stambaus bajoro dvaro sodybos struktūros, pastatų architektūros raidą nuo XVII a. iki XXI a. pradžios. Centrinio reguliaraus suplanavimo kiemo, užstatyto tiek gyvenamosios, tiek ūkinès paskirties statiniais, pradžia siekia XVII a. ir yra retas 400 metų dvaro sodybos centrinio kiemo planavimo tradiciją atspindintis erdvès organizavimo pavyzdys.

2. Raudondvario dvaro sodybos statinių architektūra iliustruoja stambaus bajoro šimtmečiais besiformavusį, gilias tradicijas išlaikiusi medinės architektūros estetikos suvokimą, kitusị nuo puošnių barokinių iki racionalių medinio klasicizmo formų. Rašytiniai šaltiniai atskleidžia buvusią 
išskirtinę Raudondvario dvaro sodybos barokinių rūmų su lodžija galiniame fasade architektūros raišką. Šalia rūmų stovintis, galimai su juo požemine jungtimi buvęs sujungtas daugiafunkcis lobyno pastatas iki XXI a. pradžios išsiskyrė architektūrinių formų daugiasluoksniškumu: nuo XVII-XVIII a. racionalaus lobyno tūrio iki XIX a. pradžios suformuoto dinamiško, su dviejų tarpsnių bokštelio antstatu silueto, savo verte prilygusiu nacionalinio lygmens vertybėms. Po gaisro bei po jo vykusių rekonstrukcijos darbų buvęs unikalus pastato tūris prarastas, lobynui suteikiant kur kas kuklesnes architektūrines formas. Išlikusių kitų centrinio kiemo ūkinių pastatų architektūra dar liudija tradicines XIX a. pirmos pusės mediniam dvarų paveldui būdingas formas (svirnai) ar funkcijos bei medžiagiškumo kaitą, tradiciškai išlaikant XVIII a. būdingą tūrị (arklidè).

3. Geometrinio suplanavimo Raudondvario dvaro sodybos sodas-parkas atspindi ilgą utilitarias ir estetines funkcijas jungiančio istorinio želdyno formavimosi evoliuciją nuo kuklios kvaterų tradicijos, būdingos XVII-XVIII a. struktūroms, XIX a. pirmoje pusėje išryškintos kompozicine ašimi, iki sudètingesnès erdvinès kompozicijos, suformuotos XIX a. antroje pusejje - XX a. pradžioje papildant centrinę istorinę sodo dalį kraštovaizdinio planavimo bruožais.

4. Nepakankama teisinė bazè turëjo neigiamos įtakos Raudondvario dvaro sodybos kaip kultūros paveldo komplekso išsaugojimo procesui. Dèl šių pokyčių pažeista dvaro sodybos planinė erdvinė struktūra, prarandamos istorinių pastatų, parko vertingosios savybès, taip ir nesuvokus šios dvaro sodybos kultūrinès vertès.

\section{Gauta 20201001}


Šaltiniai

Abramauskas Stasys, Raudonojo Dvaro buv. dvaro Vilniaus rajone aprašymas, Dokumentų byla apie Vilniaus rajono Raudondvario dvarą ir parką, 1975, in: KPCPB, f. 3, ap. 1, s. v. 231.

Budreika Gediminas, XVIII-XIX a. vietinès reikšmès architektūros paminklas Nr. 801, Buv. Raudondvario dvaro lobynas (Vilniaus r.), Paruošiamieji darbai, Fotofiksacija PD-2, Vilnius: Paminklų konservavimo institutas, 1987, in: KPCPB, f. 5, ap. 1, s. v. 3277.

Firkovičius Romanas, Raudondvario dvaro lobynas, Vilniaus r. Atv 801, Lietuvos TSR architektūros paminklai. Istoriniai tyrimai, 1981, in: VRVA, f. 1019, ap. 11, b. 236, 1. $63-65$.

Gromulas V., Riešès Raudondvario architektūrinio ansamblio trumpos istorinès žinios, LTSR kultūros ministerija, Spec. mokslinè restauracinè gamybinė dirbtuvė, Vilnius, 1968, in: VRVA, f. 1019, ap. 11, b. 90.

Gudynaitè Birutè, Bijutiškio dvaro sodybos IP 437/At ir Raudondvario dvaro sodybos IP 910/At dviejų pastatų fiziniai tyrimai, Vilnius: Kultūros paveldo centras, 2002.

Lagunavičius Alfonsas, Gulbinų paukštininkystès tarybinis ūkis. Buv. dvaro lobyno esamos padeties fotofiksacija ir restauracijos sąmatos. Aiškinamasis raštas, Vilnius: 1968, in: KPCPB, f. 5, ap. 1, s. v. 118.

Mendelevičius Jakovas, Vasiliauskienė Rasa, Raudondvario (Gulbinu) buvusio dvaro AtV 801 lobynas. Vilniaus rajonas, Restauravimo techninis projektas, Vilnius: UAB „Elvora“, 2000.

Metryka Litewska. Rejestry podymnego Wielkiego Księstwa Litewskiego Województwo wileńskie 1690 r., Optracowal Andrzej Rachuba, Warszawa: Państwowe wydawnictwo naukowe, 1989, 1. 100.

Puodžiukienė Dalè, Medinès ponu namu archtektūros raida Lietuvoje XVI a. vid. - XIX a. vid.: Daktaro diseracija, Humanitariniai mokslai, menotyra (03H), Vytauto Didžiojo

universitetas, Kaunas, 2011.

Riešès arba Raudondvario dvaro inventorius, 1764, in: LVIA, s. a. 4778, 1. 428-431.

Statistinis ir inventorinis Raudondvario dvaro aprašymas, 1847, in: LVIA, f. 394, ap. 1, b. $191,1.1$; b. $444,1.88$.

Vasiliauskienè Rasa, XVIII-XIX a. vietines reikšmès architektūros paminklas Nr. 801. Buv. Raudondvario dvaro lobynas (Vilniaus r.), Paruošiamieji darbai, Architektūriniai apmatavimai, 1988, in: KPCPB, f. 5 , ap. 1 , s. v. 3318.

Vasiliauskienè Rasa, 18-19 a. viet. reikšmès arch. paminklas buv. Raudondvario dvaro lobynas. Vilniaus r. Gulbinu tarybinis $\bar{u} k i s$, AS dalis, Darbo projektas, Paminklų restauravimo projektavimo institutas, 1989 , in: VRVA, f. 1019, ap. 12, b. 16525.

Vilniaus gubernijos matininko statistinès žinios, 1804, in: LVIA f. 526, ap. 1, b. 4, 1. 6.

Vilniaus rajono Raudondvario parko pasas, Vilnius: Lietuvos TSR valstybinis gamtos apsaugos komitetas, 1983.

\section{Literatūra}

Dabartinés lietuviu kalbos žodynas, Vilnius: Vilniaus mokslo ir enciklopedijų leidykla, 1993, p. 373.

Isokas Gediminas, Lietuvos gamtos paminklai, Vilnius: Mintis, 1995, p. 384.

Kačinskaitė Indrè, „Barokinė dvaro sodyba: istorinio vaizdo retrospekcija“, in: Kultūros paminklai, Nr. 19, Vilnius: Savastis, 2015, p. 35-56.

Lietuvos TSR kultūros paminklu sqrašas, Vilnius: Pergalè, 1973, p. 435.

Lietuvos XVII-XIX a. pradžios ikonografijos ir kartografijos šaltiniai Švedijoje, sudarytojai, teksto autoriai: dr. Ernestas Vasiliauskas (atsakingas redaktorius), dr. Gintautas Zabiela, Klaipėdos universiteto Baltijos regiono istorijos ir archeologijos institutas, Klapėda: Klaipėdos universiteto leidykla, 2013. 
Puodžiukienė Dalè, „Dvarų sodybų architektūra“, in: Lietuvos architektūros istorija, t. IV: Lietuvos etnine architektūra nuo seniausiu laiku iki 1918 m., Vilnius: Savastis, 2014, p. 354-482.

Puodžiukienė Dalè, „Dvaro sodybos pastatas povalušas: funkcija, forma ir tradicija“, in: Acta Academiae Artium Vilnensis, Vilnius, 2017, t. 86-87: (Iš)koduota istorija architektūroje, sud. Rasa Butvilaitè, Edita Povilaitytè-Leliugienè, p. 149-165.

Raudondvario dvaro sodyba, vad. Riešès Raudondvario (917). Vilniaus rajono sav., Riešès sen., Raudondvario k., Kultūros vertybiụ registras, [interaktyvus], 2019, [žiūrèta 2019-10-01], https://kvr.kpd.lt/\#/static-heritage-search.

Tauras Antanas, Mūsu parkai, Vilnius: Mokslas, 1989, p. 249. 
Summary

\title{
The Raudondvaris Manor at Lake Raudonasis Dvaras: Reflections of the 400-Year-Long Historical Development
}

\author{
Indrè Kačinskaitė
}

Keywords: Raudondvaris (Vilnius district), manor estate, history, composition, architecture, drawing, $17^{\text {th }}$ century.

One the earliest wooden manors in Lithuania, the Raudondvaris Manor reflects the development of the structure of a large landowner's estate and the architecture of its buildings from the $17^{\text {th }}$ to the early $21^{\text {st }}$ century. The appearance of its central regular courtyard with buildings of both residential and auxiliary function is dated to the $17^{\text {th }}$ century and is a rare example of spatial arrangement reflecting the tradition of central courtyard planning of the 400-year-old manor.

The architecture of the buildings on the estate illustrates a large landowner's deeply traditional perception of the aesthetics of wooden architecture, whose forms changed from ornate baroque to rational classicism over the centuries. Written sources testify to the former extraordinary architectural expression of the baroque Raudondvaris Manor with a loggia on the end façade. The multi-functional treasury building standing next to the manor and possibly connected to it by an underground tunnel up until the early $21^{\text {st }}$ century was distinguished by the multi-layered character of its architectural forms: from rational proportions in the $17^{\text {th }}-18^{\text {th }}$ century to a dynamic silhouette with an annex of a two-tier tower formed in the early $19^{\text {th }}$ century and valuable on the national scale. The architecture of the other surviving auxiliary buildings in the central courtyard reflects the traditional forms of the wooden manor heritage of the first half of the 19th century (granaries) or the change of function and materials, traditionally retaining the proportions characteristic of the $18^{\text {th }}$ century (stables). 
The estate's garden-park shows a long-time evolution of historical landscaping combining the utilitarian and aesthetical functions, from the quartering tradition characteristic of $17^{\text {th }}-18^{\text {th }}$ century structures, emphasised by adding a compositional axis in the first half of the $19^{\text {th }}$ century, to a more complex spatial composition formed from the second half of the $19^{\text {th }}$ to the early $20^{\text {th }}$ century, with features of landscape planning added to the central historical garden part. Due to the insufficient legal basis, the process of preserving the Raudondvaris Manor as a cultural heritage complex has been disrupted - the estate's spatial planning structure has been violated, and some of the valuable features of the historical buildings and the park have been lost without fully realising their cultural value. 